\title{
BMJ Open Clinical and economic characteristics of emergency department visits due to acetaminophen toxicity in the USA
}

\author{
Ahmed Altyar, ${ }^{1,2}$ Lama Kordi, ${ }^{3}$ Grant Skrepnek ${ }^{1,4}$
}

To cite: Altyar A, Kordi L, Skrepnek G. Clinical and economic characteristics of emergency department visits due to acetaminophen toxicity in the USA. BMJ Open 2015;5:e007368. doi:10.1136/bmjopen-2014007368

- Prepublication history for this paper is available online. To view these files please visit the journal online (http://dx.doi.org/10.1136/ bmjopen-2014-007368).

Received 3 December 2014 Revised 11 August 2015 Accepted 14 August 2015

CrossMark

For numbered affiliations see end of article.

Correspondence to Professor Grant Skrepnek; Grant-Skrepnek@ouhsc.edu and Ahmed Altyar; aealtyar@kau.edu.sa

\section{ABSTRACT}

Objectives: To estimate the number of acetaminophen (APAP) toxicity-related emergency department (ED) visits, and to assess their associated clinical and economic burden in the USA from 2006 to 2010.

Design: Cross-sectional, retrospective, large-scale database study.

Setting: Non-federal, non-rehabilitation, community EDs in the USA.

Participants: Inclusion criteria included any listed diagnosis identifying poisoning by aromatic analgesics paracetamol/APAP or associated supplementary code. Generalised linear models were used to investigate the association between outcomes of inpatient admission, mortality, requirement of invasive mechanical ventilation, charges and inpatient lengths of stay based on patient, hospital and clinical characteristics.

Results: Across the 625.2 million ED visits in the USA from 2006 to 2010, 411811 APAP-related toxicity ED visits were observed, with $45.5 \%$ resulting in inpatient admission, $4.7 \%$ requiring invasive mechanical ventilation and $0.6 \%$ involving death. Overall, the incidence proportion was 27.10 per 100000 US population, exceeding 70 per 100000 at age 2 years and ages $16-18$ years. The total national bill was $\$ 1.06$ billion per year (US\$ 2014), and predominantly involved females $(65.5 \%)$ and intentional self-harm $(58.4 \%)$, which were notably higher within the $12-20$ years age category (female ${ }_{12-20 \text { years }}=74.8 \%$, intentional self-harm $12-20$ years $=71.4 \%$ ). Behavioural and mental health comorbidities were relatively common and associated with an increased relative risk of admission and likelihood of charges almost entirely across all age categories of $\geq 12$ years within the multivariable analyses. The number of ED visits did not appreciably change over time, decreasing by $<2 \%$ from 2006 to 2010 ( $n=1351$ ). Multivariable results also suggested no consistent change in outcomes across the study's time horizon.

Conclusions: A substantial public health impact of APAP toxicity-related cases was observed in the US from 2006 to 2010, with incidence proportions peaking at age 2 years and ages $16-18$ years. After controlling for numerous factors, no consistent change was observed over the 5-year time horizon concerning outcomes of admission, mortality, invasive mechanical ventilation, charges or length of stay.

\section{Strengths and limitations of this study}

- This study draws on an estimated 130 million emergency department visits per year within the USA to report national estimates of case incidence and to provide assessments of clinical and economic outcomes.

- No specific categorisation existed to classify cases as being unsupervised ingestions or therapeutic misadventures (eg, overuse, medication errors); as per the type of acetaminophen (APAP) product consumed (eg, single-agent, combination products, tablets, liquid); and according to the amount ingested or serum levels observed.

- The use of $\mathrm{N}$-acetyl cysteine or gastric decontamination was also not consistently captured within the data set, nor was a designation of acute liver injury directly attributable to APAP toxicity.

\section{INTRODUCTION}

As one of the most frequently used analgesic and antipyretics worldwide, acetaminophen (APAP) is a common single or combination agent among the numerous over-the-counter and prescription products. ${ }^{1}$ Though considered generally safe at approved doses, APAP has a known and established toxicity pattern at higher doses. ${ }^{2}$ Of all pharmaceuticals involved in human overdoses, analgesics are considered the most frequently involved. ${ }^{2}$ US poison centre data indicate that APAP combinations were associated with the fourth highest number of fatalities compared with other medications in 2012, with APAP overdose being the principal cause of toxic drug ingestion that ultimately contributed to $39 \%$ of all acute liver failures. ${ }^{2}{ }^{3}$ Hepatotoxicity is a well-recognised adverse event associated with APAP overdose that may result in liver failure and death. ${ }^{4}$ The percentage of APAP-induced acute liver failure cases increased from $28 \%$ in 1998 to $51 \%$ in 2003 , establishing this medication as the most common cause of acute liver failure in the 
USA. ${ }^{4}$ Overall, previous studies have suggested that APAP overdoses leads annually to $56000-78000$ emergency department (ED) visits, 26 000-34 000 hospitalisations, and an estimated 500 deaths. ${ }^{5-8}$

The US Food and Drug Administration (FDA) has issued several updates in recent years involving APAP to increase the safety and limit the toxicity associated with the use of this medication, presented in figure $1 .{ }^{9-13}$

Given the aforementioned, the overall purpose of this investigation was to estimate the number of APAP toxicity-related ED visits, and to assess their associated clinical and economic burden in the USA from 2006 to 2010. More specifically, the objectives were to assess the relationships between outcomes of inpatient admission, mortality, requirement of invasive mechanical ventilation, charges and inpatient lengths of stay based on patient, hospital and clinical characteristics.

\section{METHODS}

This cross-sectional, retrospective investigation utilised 2006-2010 Nationwide Emergency Department Sample (NEDS) from the Agency for Healthcare Research and Quality (AHRQ). ${ }^{14}$ These data comprise nationally representative case presentations across hospital-based EDs within the non-federal, non-rehabilitation, community facilities and generalising, overall, to approximately 130 million ED visits that occur in the USA per year. ${ }^{14}$ Given the fully de-identified and anonymised data, this research is classified as exempt via human participants protection. $^{14}$

Consistent with previous research, ED visits involving APAP toxicity were identified based on the inclusion criteria of any listed diagnosis according to International Classification of Disease, Ninth edition, Clinical Manifestations (ICD-9-CM) codes identifying poisoning by aromatic analgesics paracetamol/APAP (ie, 965.4) or associated supplementary code (ie, E850.4: accidental poisoning by aromatic analgesics paracetamol/APAP).$^{5-8} 1516$ Previous research has addressed the challenges faced regarding the sensitivity and specificity of utilising diagnosis or supplementary codes to identify APAP toxicity-related cases, suggesting that the use of these aforementioned codes remains a valid approach. ${ }^{15}$ All ages were investigated and stratified according to the following age categories: (A) 0-11; (B) 12-20; (C) 21-64; and (D) $\geq 65$ years.

Figure 1 US Food and Drug Administration sequence of updates concerning acetaminophen. 
Clinical outcomes assessed were admission to an inpatient setting from the ED, mortality and requirement of invasive mechanical ventilation (ie, as a proxy for acute respiratory distress syndrome and supportive care measures associated with APAP toxicity disease progression or acute liver failure). ${ }^{17} 18$ Economic outcomes analysed involved inflation-adjusted charges (US\$2014) and inpatient length of stay. Independent predictor variables analysed were patient demographics (ie, age category, sex, income quartile, age, primary payer, rural location defined by communities $\leq 50000$ residents), ED and hospital characteristics (geographic region, urban/ rural location, teaching status), clinical case-mix disease severity measured via Elixhauser comorbidities (a validated case-mix risk severity measure comprising of 30 disease states), designation of intentional self-harm, and year (2006-2010). ${ }^{14} 19$ Notably, if any given Elixhauser comorbidity was observed in $<0.1 \%$ of cases within any age category, it was omitted to allow for appropriate statistical inference; peptic ulcer disease with bleeding was consistently observed to be $<0.1 \%$ of cases and summarily removed from the study. ${ }^{67}$

Multivariable analyses for outcomes of admission to an inpatient setting from the ED and mortality were conducted using a multinomial logit regression, specifying treat-and-release ED cases as a baseline comparator. ${ }^{20} 21$ The requirement of invasive mechanical ventilation was analysed via a logistic regression. Generalised linear models were used to analyse inflation-adjusted charges and inpatient length of stay, specified by a $\gamma$ distribution with log link and negative binomial distribution with $\log$ link, respectively. ${ }^{21}$ Accordingly, results may be interpreted generally as relative risk measures, superficially as: a relative risk ratio (RRR) in a multinomial regression; an OR in a logistic regression; an exponentiated $\beta$ value $(\exp (\mathrm{b}))$ in a $\gamma$ regression; and an incidence ratio in a negative binomial regression. ${ }^{21}$ Therein, estimated coefficients may be interpreted as suggesting a reduced likelihood $(<1.00)$ or no difference in likelihood $(=1.00)$ or an increased likelihood (>1.00).

The Simes ${ }^{22}$ procedure to control for false-discovery rates was used to control for multiple comparisons across age categories within the analysis of invasive mechanical ventilation, charges and length of stay, yielding critical $\mathrm{p}$ values for significance of $0.028,0.036$ and 0.024, respectively. Inherently controlling for multiple comparisons by definition, the multinomial regression of disposition from the ED used an $\alpha$ level of 0.05 for significance and established treat-and-release cases as the baseline comparator. Owing to the complex nature of sampling employed by the NEDS, Taylor series weighting procedures were incorporated to yield national estimates. ${ }^{14}$ All analyses were conducted using SAS V.9.2 (Cary, North Carolina, USA) and STATA SE V.12.1 (College Station, Texas, USA).

\section{RESULTS}

Across the 625.2 million ED visits in the USA from 2006 to 2010, APAP-related toxicity was observed in 411881 ED visits, with peaks occurring at approximately ages $0-5,15-20$ and $35-45$ years (figure 2). Overall, the incidence proportion of APAP toxicity-related ED visits according to age per 100000 per US population was 27.10 , and by age category: 17.29 for ages $0-11$ years; 63.17 for ages 12-20 years; 27.77 for ages 21-64 years; and 8.18 for ages 65 years and over. Reflected in figure 3, peak incidence proportions exceeding 70 per 100000 US population were observed at age 2 years (78.39 per 100000$)$ and ages $16-18$ years $(76.16,77.52$ and 74.00 per 100000 , respectively). Inpatient admissions averaged 12.46 per 100000 US population, being
Figure 2 Overall number of acetaminophen (APAP) toxicity-related emergency department (ED) cases according to age, 2006-2010.

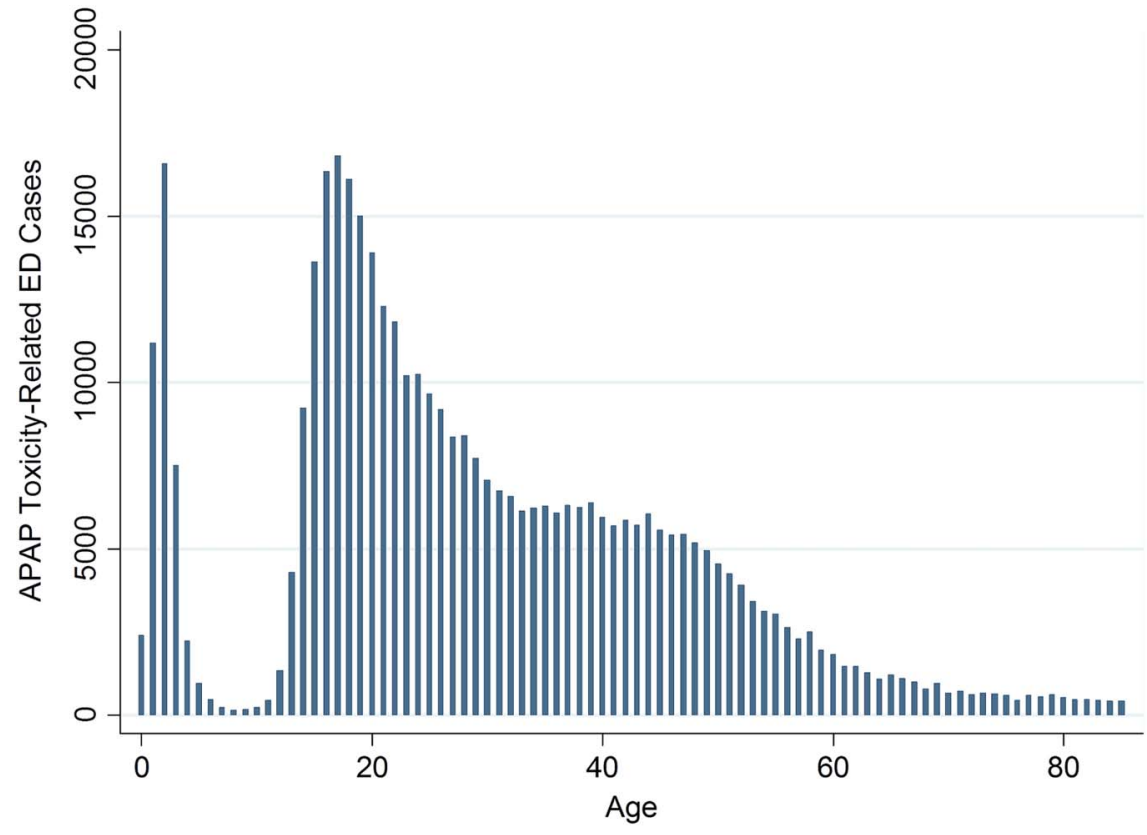


Figure 3 Age-adjusted for acetaminophen (APAP) toxicity-related emergency department (ED) cases per 100000 US population, 20062010. Base US populations for 2006-2010 obtained from the Centers for Disease Control and Prevention, National Vital Statistics System, Vintage 2012 bridged race postcensus US resident population estimates.

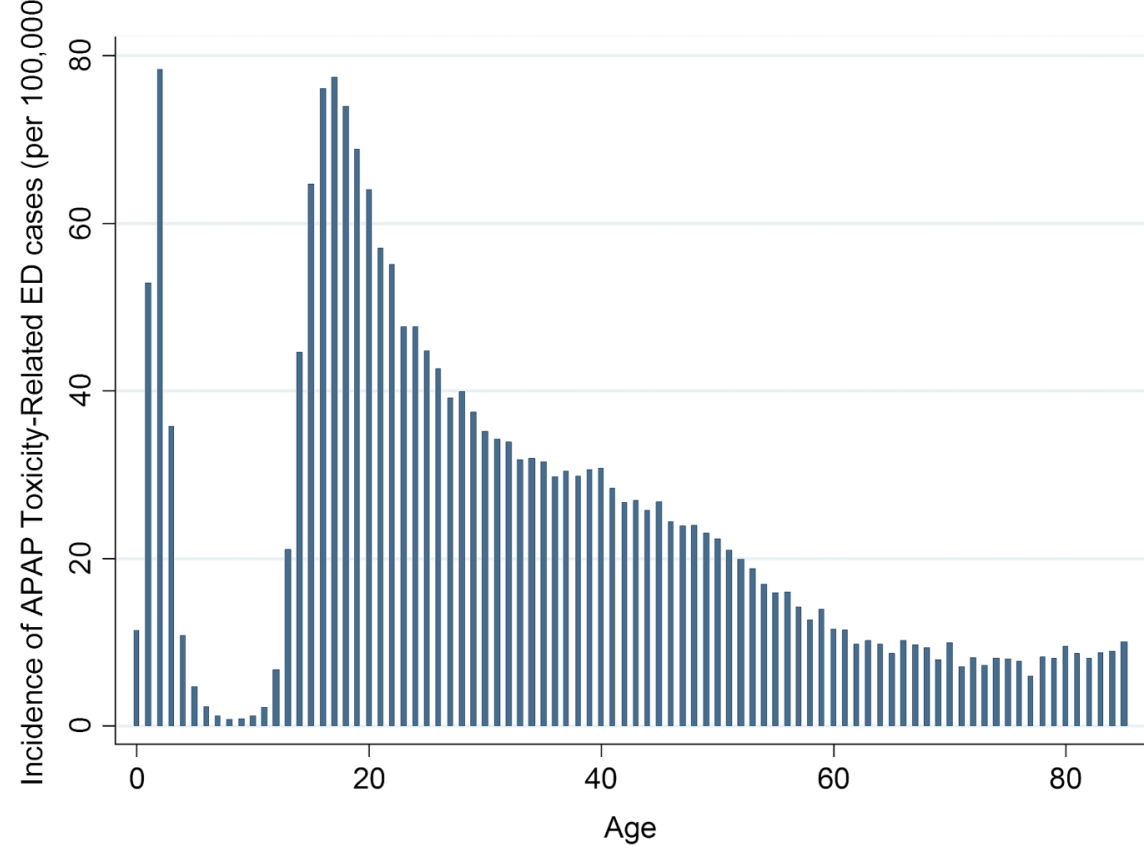

lowest for age group $<12$ years $(0.50$ per 100000$)$ and highest for cases from age group 12-20 years (23.34 per $100000)$; peaks were noted at ages 18 (33.55 per $100000)$ and 19 years (31.07 per 100000$)$.

In general, cases involved females $(65.5 \%)$ averaging $29.3( \pm 17.6)$ years of age with $3.1( \pm 4.4)$ days of inpatient lengths of stay, and these involved intentional self-harm $(58.4 \%)$. Within the $12-20$ years age category, cases were markedly female $(74.8 \%)$ and involved intentional self-harm $(71.4 \%)$. Among the APAP-related cases presenting to the ED, $45.4 \%$ resulted in direct inpatient admissions, highest in percentage terms among cases age $\geq 65$ years $(66.0 \%)$, even though this age category constituted an age-adjusted 5.68 admissions per 100000 US population. Those treated-and-released directly in the ED involved $37.4 \%$ of cases, particularly characteristic among cases $<12$ years $(92.7 \%)$. The most common Elixhauser comorbidities observed were depression (25.0\%), drug abuse (15.6\%), psychoses (15.3\%), alcohol abuse $(13.7 \%)$, and fluid and electrolyte disorders $(13.6 \%)$; no Elixhauser comorbidities were noted among $38.0 \%$. Inpatient mortality was low $(0.6 \%)$, and the requirement of invasive mechanical ventilation was for $4.7 \%$. The total national bill across the 5-year time horizon was $\$ 5.30$ billion (US\$ 2014), equating to $\$ 12766( \pm 28414)$ per case. The full descriptive statistics appear in table 1 .

Multivariable analysis: inpatient admission, mortality, invasive mechanical ventilation

Results of the multinomial logit regression of patient disposition from the ED (table 2) indicated that numerous patient, hospital and clinical characteristics were associated with an increased likelihood of admission or death. After statistically controlling for numerous factors, rural patient residence suggested statistical significance $(p<0.05)$, with increased relative risk of admission among the $0-11$, 12-20, and 21-64-year-old categories $\left(\mathrm{RRR}_{0-11}=2.26\right.$, $\left.\mathrm{RRR}_{12-20}=1.30, \mathrm{RRR}_{21-64}=1.24\right)$. Intentional self-harm was also associated with over a $3 \times$ increase odds of admission across all age categories $\geq 12$ years $(p<0.05)$; was almost perfectively predictive of mortality cases among those 12-20 years of age; and was associated with a $8.57 \times$ $(p<0.001)$ for those aged $\geq 65$ years.

Comorbidities of liver disease, coagulopathy, fluid and electrolyte disorders, and weight loss/cachexia were associated with statistical significance $(\mathrm{p}<0.05)$, and large relative risks for both admission and mortality across age groups (sample size permitting for analysis). Specifically among paediatric cases $<12$ years of age, other neurological disorders, fluid and electrolyte disorders, and blood or deficiency anaemia were significantly associated with increased admissions $(\mathrm{p}<0.05)$. Across other age categories while considering admissions alone, comorbid conditions of valvular disease, peripheral vascular disorders, hypertension with complications, other neurological disorders, obesity, deficiency or other anaemia, alcohol abuse, psychoses and depression were significantly associated with an increased relative risk across all age groups $(p<0.05)$. Over time, no sustained decrease in admissions or mortality was observed consistently across the age categories.

The requirement of invasive mechanical ventilation (table 3) indicated that chronic pulmonary disease, coagulopathy, and fluid and electrolyte disorders were significant predictors among cases aged $\geq 12$ years $(\mathrm{p}<0.028)$. Intentional self-harm was associated with a $1.49 \times$ higher odds among those aged 21-64 years, and a $2.42 \times$ higher odds among cases aged $\geq 65$ years $(\mathrm{p}<0.028)$. Other neurological disorders, blood loss or 
Table 1 Descriptive statistics of ED cases associated with APAP toxicity according to age category in the USA, 2006-2010

\begin{tabular}{|c|c|c|c|c|c|}
\hline & $\begin{array}{l}\text { Age } 11 \text { years and below } \\
(\mathrm{N}=42623)\end{array}$ & $\begin{array}{l}\text { Age } 12-20 \text { years } \\
(\mathrm{N}=106725)\end{array}$ & $\begin{array}{l}\text { Age } 21-64 \text { years } \\
(\mathrm{N}=246640)\end{array}$ & $\begin{array}{l}\text { Age } 65 \text { years and above } \\
(\mathrm{N}=15893)\end{array}$ & $\begin{array}{l}\text { Overall } \\
(\mathrm{N}=411881)\end{array}$ \\
\hline \multicolumn{6}{|l|}{ Patient characteristics } \\
\hline Age $(m e a n \pm S D)$ & $2.2 \pm 1.7$ & $16.9 \pm 2.1$ & $36.4 \pm 11.4$ & $75.2 \pm 7.9$ & $29.3 \pm 17.6$ \\
\hline Female sex & $48.3 \%$ & $74.8 \%$ & $64.4 \%$ & $68.0 \%$ & $65.5 \%$ \\
\hline Payer, commercial insurance & $38.1 \%$ & $26.4 \%$ & $20.4 \%$ & $1.6 \%$ & $23.1 \%$ \\
\hline Medicare & $\leq 0.1 \%$ & $0.2 \%$ & $10.0 \%$ & $88.3 \%$ & $9.5 \%$ \\
\hline Medicaid & $48.9 \%$ & $51.5 \%$ & $35.1 \%$ & $7.8 \%$ & $39.7 \%$ \\
\hline Other & $12.8 \%$ & $21.8 \%$ & $34.5 \%$ & $2.3 \%$ & $27.7 \%$ \\
\hline Income quartile, lowest & $24.3 \%$ & $23.2 \%$ & $28.1 \%$ & $24.4 \%$ & $26.3 \%$ \\
\hline 2nd quartile & $28.3 \%$ & $27.5 \%$ & $28.5 \%$ & $27.0 \%$ & $28.2 \%$ \\
\hline 3rd quartile & $25.5 \%$ & $25.6 \%$ & $24.5 \%$ & $25.4 \%$ & $24.9 \%$ \\
\hline 4th quartile & $21.9 \%$ & $23.8 \%$ & $18.9 \%$ & $23.3 \%$ & $20.6 \%$ \\
\hline Rural residence & $19.6 \%$ & $16.7 \%$ & $17.1 \%$ & $17.9 \%$ & $17.3 \%$ \\
\hline \multicolumn{6}{|l|}{ Hospital characteristics } \\
\hline Region, Northeast & $14.4 \%$ & $16.2 \%$ & $15.6 \%$ & $16.4 \%$ & $15.6 \%$ \\
\hline Midwest & $25.6 \%$ & $18.2 \%$ & $26.4 \%$ & $21.0 \%$ & $26.6 \%$ \\
\hline South & $32.1 \%$ & $30.0 \%$ & $34.7 \%$ & $34.5 \%$ & $33.2 \%$ \\
\hline West & $18.1 \%$ & $25.6 \%$ & $23.3 \%$ & $28.2 \%$ & $24.5 \%$ \\
\hline Rural facility & $18.5 \%$ & $15.3 \%$ & $15.3 \%$ & $16.2 \%$ & $15.6 \%$ \\
\hline Teaching facility & $38.9 \%$ & $39.9 \%$ & $39.5 \%$ & $35.7 \%$ & $39.4 \%$ \\
\hline \multicolumn{6}{|l|}{ Clinical characteristics } \\
\hline Congestive heart failure & $\leq 0.1 \%$ & $\leq 0.1 \%$ & $0.7 \%$ & $8.8 \%$ & $0.8 \%$ \\
\hline Valvular disease & $\leq 0.1 \%$ & $\leq 0.1 \%$ & $0.6 \%$ & $3.3 \%$ & $0.5 \%$ \\
\hline Pulmonary circulation disorders & $\leq 0.1 \%$ & $\leq 0.1 \%$ & $0.2 \%$ & $1.4 \%$ & $0.2 \%$ \\
\hline Peripheral vascular disorders & $\leq 0.1 \%$ & $\leq 0.1 \%$ & $0.3 \%$ & $3.8 \%$ & $0.3 \%$ \\
\hline Hypertension with complications & $\leq 0.1 \%$ & $\leq 0.1 \%$ & $0.7 \%$ & $7.6 \%$ & $0.7 \%$ \\
\hline Paralysis & $\leq 0.1 \%$ & $\leq 0.1 \%$ & $0.4 \%$ & $1.5 \%$ & $0.3 \%$ \\
\hline Other neurological disorders & $0.3 \%$ & $2.2 \%$ & $7.4 \%$ & $14.6 \%$ & $5.6 \%$ \\
\hline Chronic pulmonary disease & $2.0 \%$ & $4.9 \%$ & $7.8 \%$ & $19.2 \%$ & $6.9 \%$ \\
\hline Diabetes with complications & $\leq 0.1 \%$ & $\leq 0.1 \%$ & $0.5 \%$ & $2.0 \%$ & $0.4 \%$ \\
\hline Hypothyroidism & $\leq 0.1 \%$ & $0.5 \%$ & $2.9 \%$ & $11.9 \%$ & $2.3 \%$ \\
\hline Renal failure & $\leq 0.1 \%$ & $\leq 0.1 \%$ & $0.8 \%$ & $7.3 \%$ & $0.8 \%$ \\
\hline Liver disease & $\leq 0.1 \%$ & $0.2 \%$ & $2.2 \%$ & $1.7 \%$ & $1.4 \%$ \\
\hline HIV/AIDS & $\leq 0.1 \%$ & $\leq 0.1 \%$ & $0.2 \%$ & $\leq 0.1 \%$ & $\leq 0.1 \%$ \\
\hline PUD, excluding bleeding & $\leq 0.1 \%$ & $\leq 0.1 \%$ & $\leq 0.1 \%$ & $\leq 0.1 \%$ & $\leq 0.1 \%$ \\
\hline Lymphoma & $\leq 0.1 \%$ & $\leq 0.1 \%$ & $\leq 0.1 \%$ & $\leq 0.1 \%$ & $\leq 0.1 \%$ \\
\hline Metastatic cancer & $\leq 0.1 \%$ & $\leq 0.1 \%$ & $\leq 0.1 \%$ & $1.0 \%$ & $0.2 \%$ \\
\hline Solid tumour & $\leq 0.1 \%$ & $\leq 0.1 \%$ & $0.3 \%$ & $2.1 \%$ & $0.2 \%$ \\
\hline $\begin{array}{l}\text { Rheumatoid arthritis/collagen vascular } \\
\text { disease }\end{array}$ & $\leq 0.1 \%$ & $\leq 0.1 \%$ & $0.9 \%$ & $3.1 \%$ & $0.7 \%$ \\
\hline Coagulopathy & $\leq 0.1 \%$ & $0.5 \%$ & $2.3 \%$ & $4.2 \%$ & $1.7 \%$ \\
\hline Obesity & $\leq 0.1 \%$ & $1.2 \%$ & $3.3 \%$ & $2.4 \%$ & $2.4 \%$ \\
\hline
\end{tabular}




\begin{tabular}{|c|c|c|c|c|c|}
\hline & $\begin{array}{l}\text { Age } 11 \text { years and below } \\
(\mathrm{N}=42623)\end{array}$ & $\begin{array}{l}\text { Age } 12-20 \text { years } \\
(N=106725)\end{array}$ & $\begin{array}{l}\text { Age } 21-64 \text { years } \\
(\mathrm{N}=246640)\end{array}$ & $\begin{array}{l}\text { Age } 65 \text { years and above } \\
(\mathrm{N}=15 \text { 893) }\end{array}$ & $\begin{array}{l}\text { Overall } \\
(\mathrm{N}=411881)\end{array}$ \\
\hline Weight loss/cachexia & $\leq 0.1 \%$ & $\leq 0.1 \%$ & $0.8 \%$ & $3.2 \%$ & $0.6 \%$ \\
\hline Fluid and electrolyte disorders & $0.7 \%$ & $8.1 \%$ & $17.2 \%$ & $29.4 \%$ & $13.6 \%$ \\
\hline Blood loss or deficiency anaemia & $\leq 0.1 \%$ & $1.5 \%$ & $4.3 \%$ & $12.3 \%$ & $3.4 \%$ \\
\hline Alcohol abuse & $\leq 0.1 \%$ & $5.7 \%$ & $19.8 \%$ & $8.6 \%$ & $13.7 \%$ \\
\hline Drug abuse & $\leq 0.1 \%$ & $12.1 \%$ & $20.3 \%$ & $6.3 \%$ & $15.6 \%$ \\
\hline Psychoses & $\leq 0.1 \%$ & $11.2 \%$ & $19.8 \%$ & $13.3 \%$ & $15.3 \%$ \\
\hline Depression & $\leq 0.1 \%$ & $27.4 \%$ & $28.4 \%$ & $22.6 \%$ & $25.0 \%$ \\
\hline No Elixhauser comorbidities present & $96.4 \%$ & $47.0 \%$ & $25.7 \%$ & $12.6 \%$ & $38.0 \%$ \\
\hline Intentional self-harm & $\leq 0.1 \%$ & $71.4 \%$ & $64.2 \%$ & $34.9 \%$ & $58.4 \%$ \\
\hline \multicolumn{6}{|l|}{ Calendar year } \\
\hline 2006 & $18.1 \%$ & $21.1 \%$ & $19.5 \%$ & $17.5 \%$ & $19.7 \%$ \\
\hline 2007 & $21.0 \%$ & $20.5 \%$ & $19.6 \%$ & $17.0 \%$ & $19.9 \%$ \\
\hline 2008 & $21.8 \%$ & $21.1 \%$ & $20.6 \%$ & $20.1 \%$ & $20.8 \%$ \\
\hline 2009 & $20.8 \%$ & $19.7 \%$ & $20.4 \%$ & $21.8 \%$ & $20.3 \%$ \\
\hline 2010 & $18.3 \%$ & $17.6 \%$ & $20.0 \%$ & $23.6 \%$ & $19.3 \%$ \\
\hline \multicolumn{6}{|l|}{ Outcomes } \\
\hline Disposition, treat-and-release & $92.7 \%$ & $38.4 \%$ & $28.1 \%$ & $23.8 \%$ & $37.4 \%$ \\
\hline Transfer & $2.5 \%$ & $22.4 \%$ & $14.0 \%$ & $6.3 \%$ & $14.7 \%$ \\
\hline Admission & $2.9 \%$ & $37.0 \%$ & $55.1 \%$ & $66.0 \%$ & $45.4 \%$ \\
\hline Death & $\leq 0.1 \%$ & $\leq 0.1 \%$ & $0.7 \%$ & $3.4 \%$ & $0.6 \%$ \\
\hline Other & $1.9 \%$ & $2.2 \%$ & $1.9 \%$ & $0.5 \%$ & $1.9 \%$ \\
\hline $\begin{array}{l}\text { Average ED and inpatient charge (US\$ } \\
\text { 2014) (mean } \pm S D)\end{array}$ & $\$ 1343 \pm 3162$ & $\$ 7884 \pm 13034$ & $\$ 15824 \pm 31404$ & $\$ 28631 \pm 50515$ & $\$ 12766 \pm 28414$ \\
\hline $\begin{array}{l}\text { Annual: total national bill (US\$2014) } \\
(\text { mean } \pm \text { SD) }\end{array}$ & $\$ 11.45$ million & $\$ 168.28$ million & $\$ 789.11$ million & $\$ 91.00$ million & $\$ 1059.86$ million \\
\hline $\begin{array}{l}\text { 2006-2010: total national bill (US\$ 2014) } \\
(\text { mean } \pm \text { SD) }\end{array}$ & $\$ 0.06$ billion & $\$ 0.84$ billion & $\$ 3.95$ billion & $\$ 0.46$ billion & $\$ 5.30$ billion \\
\hline Inpatient length of stay (mean $\pm S D$ ) & $1.8 \pm 1.8$ & $2.3 \pm 2.2$ & $3.2 \pm 4.5$ & $4.9 \pm 6.9$ & $3.1 \pm 4.4$ \\
\hline Invasive mechanical ventilation & $\leq 0.1 \%$ & $1.2 \%$ & $6.8 \%$ & $8.6 \%$ & $4.7 \%$ \\
\hline ED visits per 100000 persons per year* & 17.29 & 63.17 & 27.77 & 8.18 & 27.10 \\
\hline $\begin{array}{l}\text { Inpatient admissions per } 100000 \\
\text { persons per year* }\end{array}$ & 0.50 & 23.34 & 15.50 & 5.68 & 12.46 \\
\hline
\end{tabular}


Table 2 Patient disposition of admission or mortality versus treat-and-release from APAP toxicity-related presentation to the ED, 2006-2010

\begin{tabular}{|c|c|c|c|c|c|c|c|c|}
\hline & \multicolumn{2}{|l|}{$\begin{array}{l}\text { Age } 11 \text { years and below } \\
(\mathrm{N}=42623)\end{array}$} & \multicolumn{2}{|c|}{ Age $12-20$ years $(\mathrm{N}=106725)$} & \multicolumn{2}{|c|}{ Age $21-64$ years $(\mathrm{N}=246640)$} & \multicolumn{2}{|c|}{ Age 65 years and above $(\mathrm{N}=15893)$} \\
\hline & $\begin{array}{l}\text { Admission } \\
\text { (RRR, 95th Cl) }\end{array}$ & $\begin{array}{l}\text { (RRR, } \\
\text { 95th CI) }\end{array}$ & $\begin{array}{l}\text { Admission } \\
\text { (RRR, 95th Cl) }\end{array}$ & $\begin{array}{l}\text { Mortality } \\
\text { (RRR, 95th Cl) }\end{array}$ & $\begin{array}{l}\text { Admission } \\
\text { (RRR, 95th Cl) }\end{array}$ & $\begin{array}{l}\text { Mortality } \\
\text { (RRR, 95th Cl) }\end{array}$ & $\begin{array}{l}\text { Admission } \\
\text { (RRR, 95th Cl) }\end{array}$ & $\begin{array}{l}\text { Mortality } \\
\text { (RRR, 95th Cl) }\end{array}$ \\
\hline \multicolumn{9}{|l|}{ Patient characteristics } \\
\hline Age & $1.11^{\star *}(1.03$ to 1.19$)$ & - & $1.09^{\star \star \star}(1.06$ to 1.11$)$ & $1.49^{*}(1.01$ to 2.19$)$ & $1.01^{\star \star \star}(1.01$ to 1.02$)$ & $1.05^{\star \star \star}(1.04$ to 1.06$)$ & 1.00 (0.99 to 1.01$)$ & $1.09^{\star \star}(1.03$ to 1.14$)$ \\
\hline Female sex & $1.01(0.77$ to 1.33$)$ & - & $0.97(0.89$ to 1.06$)$ & $1.94(0.28$ to 13.60$)$ & $0.90^{\star \star *}(0.85$ to 0.95$)$ & 0.96 (0.76 to 1.22$)$ & 1.24 (0.99 to 1.56$)$ & $0.54(0.25$ to 1.15$)$ \\
\hline \multicolumn{9}{|c|}{ Payer (vs commercial insurance) } \\
\hline Medicare & - & - & $0.54^{*}(0.30$ to 0.97$)$ & Omitted $^{A}$ & $0.83^{\star *}(0.75$ to 0.92$)$ & 0.87 (0.59 to 1.28$)$ & 1.17 (0.49 to 2.78$)$ & $0.12^{* *}(0.03$ to 0.55$)$ \\
\hline Medicaid & $0.62^{\star \star}(0.45$ to 0.86$)$ & - & $0.97(0.87$ to 1.07$)$ & $0.42(0.09$ to 1.85$)$ & $1.02(0.94$ to 1.11$)$ & 0.90 (0.64 to 1.27$)$ & $0.64(0.25$ to 1.69$)$ & $0.04^{* \star}(0.01$ to 0.28$)$ \\
\hline Other & $0.58^{*}(0.37$ to 0.92$)$ & - & $0.86^{*}(0.76$ to 0.98$)$ & $0.32(0.07$ to 1.46$)$ & $0.90^{*}(0.83$ to 0.98$)$ & 0.87 (0.62 to 1.22$)$ & $0.31^{*}(0.10$ to 0.93$)$ & Omitted $^{A}$ \\
\hline \multicolumn{9}{|c|}{ Income quartile (vs lowest) } \\
\hline 2nd quartile & $1.12(0.79$ to 1.59$)$ & - & $1.13^{\star}(1.00$ to 1.27$)$ & $2.50(0.21$ to 29.40$)$ & 1.05 (0.97 to 1.14$)$ & $0.93(0.67$ to 1.28$)$ & 0.84 (0.61 to 1.14$)$ & $0.23^{*}(0.07$ to 0.74$)$ \\
\hline 3rd quartile & 0.75 (0.48 to 1.16$)$ & - & $1.15^{*}(1.02$ to 1.29$)$ & $13.40^{*}(1.59$ to 113.21$)$ & $1.08(0.98$ to 1.20$)$ & $1.21(0.86$ to 1.69$)$ & $1.08(0.75$ to 1.54$)$ & $1.03(0.32$ to 3.24$)$ \\
\hline 4th quartile & $0.90(0.58$ to 1.39$)$ & - & $1.24^{\star \star}(1.07$ to 1.43$)$ & Omitted $^{A}$ & $1.26^{* \star *}(1.13$ to 1.41$)$ & $1.20(0.83$ to 1.73$)$ & $1.18(0.83$ to 1.69$)$ & $1.76(0.64$ to 4.85$)$ \\
\hline Rural residence & $2.26^{*}(1.19$ to 4.30$)$ & - & $1.30^{*}(1.06$ to 1.60$)$ & $0.82(0.18$ to 3.78$)$ & $1.24^{\star \star}(1.07$ to 1.44$)$ & 1.21 (0.72 to 2.03$)$ & $1.36(0.76$ to 2.43$)$ & $1.88(0.44$ to 7.97$)$ \\
\hline \multicolumn{9}{|c|}{ Hospital characteristics } \\
\hline Rural location & 0.53 (0.26 to 1.12$)$ & - & $0.79^{*}(0.62$ to 0.99$)$ & $1.48(0.15$ to 14.19$)$ & $0.67^{\star \star \star}(0.56$ to 0.80$)$ & $0.42^{\star \star}(0.21$ to 0.81$)$ & $0.63(0.35$ to 1.14$)$ & 1.27 (0.34 to 4.68$)$ \\
\hline Teaching facility & $3.13^{\star \star \star}(2.17$ to 4.50$)$ & - & $1.55^{\star \star \star}(1.35$ to 1.79$)$ & 5.08 (0.82 to 31.72$)$ & $0.98^{*}(0.86$ to 1.12$)$ & $1.04(0.79$ to 1.37$)$ & $1.31^{*}(1.03$ to 1.68$)$ & $1.58(0.68$ to 3.66$)$ \\
\hline \multicolumn{9}{|c|}{ Region (vs Northeast) } \\
\hline Midwest & $0.72(0.47$ to 1.12$)$ & - & 0.96 (0.81 to 1.14$)$ & $1.18(0.11$ to 13.16$)$ & 0.87 (0.72 to 1.04$)$ & $0.59^{*}(0.40$ to 0.90$)$ & $0.63^{*}(0.44$ to 0.90$)$ & $0.48(0.16$ to 1.45$)$ \\
\hline South & 0.79 (0.51 to 1.22$)$ & - & 0.85 (0.72 to 1.02$)$ & $1.92(0.17$ to 21.10$)$ & $0.86(0.72$ to 0.99$)$ & $0.79(0.55$ to 1.14$)$ & 0.85 (0.61 to 1.18$)$ & $0.36^{*}(0.14$ to 0.92$)$ \\
\hline West & 0.65 (0.39 to 1.08$)$ & - & $0.62^{\star \star \star}(0.52$ to 0.74$)$ & 0.39 (0.01 to 12.73$)$ & $0.51^{\star \star \star}(0.43$ to 0.59$)$ & $0.52^{\star \star}(0.35$ to 0.77$)$ & $0.54^{\star \star}(0.38$ to 0.77$)$ & $0.26^{*}(0.08$ to 0.82$)$ \\
\hline \multicolumn{9}{|c|}{ Clinical characteristics } \\
\hline $\begin{array}{l}\text { Congestive heart } \\
\text { failure }\end{array}$ & - & - & - & - & 1.48 (0.95 to 2.31$)$ & 1.67 (0.80 to 3.49$)$ & $3.36^{\star \star *}(2.01$ to 5.63$)$ & 1.64 (0.55 to 4.87$)$ \\
\hline Valvular disease & - & - & $3.94^{*}(1.15$ to 13.50$)$ & Omitted $^{A}$ & $4.47^{\star \star *}(2.70$ to 7.40$)$ & $2.06(0.60$ to 7.01$)$ & $3.64^{\star \star}(1.67$ to 7.92$)$ & 3.55 (0.51 to 24.58$)$ \\
\hline $\begin{array}{l}\text { Pulmonary } \\
\text { circulation } \\
\text { disorders }\end{array}$ & - & - & - & - & $2.35^{*}(1.03$ to 5.40$)$ & $8.50^{\star \star}$ (2.54 to 28.43$)$ & $3.70(0.39$ to 35.40$)$ & Omitted $^{A}$ \\
\hline $\begin{array}{l}\text { Peripheral } \\
\text { vascular } \\
\text { disorders }\end{array}$ & - & - & - & - & $3.15^{\star \star \star}(1.55$ to 6.37$)$ & 2.64 (0.59 to 11.89$)$ & $2.88^{\star \star}(1.32$ to 6.28$)$ & 5.77 (0.96 to 34.48$)$ \\
\hline $\begin{array}{l}\text { Hypertension } \\
\text { with } \\
\text { complications }\end{array}$ & - & - & $2.46^{\star \star \star}(1.53$ to 3.96$)$ & Omitted $^{A}$ & $2.27^{\star \star}$ (1.32 to 3.92$)$ & 1.66 (0.59 to 4.68$)$ & $5.74^{\star \star *}(2.32$ to 14.21$)$ & 0.66 (0.06 to 6.75$)$ \\
\hline Paralysis & - & - & 1.54 (0.31 to 7.54$)$ & Omitted $^{A}$ & $3.28^{* * *}(1.90$ to 5.65$)$ & $11.47^{\star \star \star}$ (4.84 to 27.23$)$ & 1.75 (0.57 to 5.38$)$ & $1.20(0.14$ to 10.13$)$ \\
\hline $\begin{array}{l}\text { Other } \\
\text { neurological } \\
\text { disorders }\end{array}$ & $24.83^{\star \star \star}(10.48$ to 58.83$)$ & - & $3.14^{\star \star \star}(2.40$ to 4.12$)$ & $50.97^{\star \star \star}(10.75$ to 241.71$)$ & $2.19^{\star \star \star}(1.95$ to 2.47$)$ & $2.21^{\star \star *}(1.55$ to 3.15$)$ & $1.97^{\star * \star}(1.40$ to 2.78$)$ & $1.48(0.67$ to 3.27$)$ \\
\hline $\begin{array}{l}\text { Chronic } \\
\text { pulmonary } \\
\text { disease }\end{array}$ & 1.94 (0.95 to 3.96$)$ & - & $2.35^{\star \star \star}$ (1.93 to 2.86$)$ & Omitted $^{A}$ & $2.01^{\star \star *}$ (1.78 to 2.28$)$ & 1.29 (0.83 to 2.00$)$ & $3.21^{* \star *}(2.27$ to 4.54$)$ & $5.16^{* \star}(1.75$ to 15.25$)$ \\
\hline $\begin{array}{l}\text { Diabetes with } \\
\text { complications }\end{array}$ & - & - & 0.97 (0.58 to 1.64$)$ & Omitted $^{A}$ & $4.52^{\star \star \star}(2.55$ to 8.01$)$ & $3.57^{\star}$ (1.01 to 12.64$)$ & 2.34 (0.62 to 8.88 ) & $16.60(0.12$ to 225.36$)$ \\
\hline Hypothyroidism & - & - & 1.04 (0.58 to 1.85$)$ & Omitted ${ }^{A}$ & $2.67^{\star \star \star}(2.16$ to 3.31$)$ & $1.52(0.77$ to 2.99$)$ & $2.15^{* * *}(1.43$ to 3.24$)$ & 2.17 (0.75 to 6.33$)$ \\
\hline Renal failure & - & - & $2.11(0.24$ to 18.52$)$ & Omitted ${ }^{A}$ & $2.39^{\star \star \star}(1.51$ to 3.80$)$ & $3.16^{\star \star}(1.38$ to 7.25$)$ & 0.50 (0.22 to 1.12$)$ & $1.06(0.13$ to 8.44$)$ \\
\hline Liver disease & - & - & $2.98^{*}(1.03$ to 8.64$)$ & Omitted $^{B}$ & $12.13^{\star \star \star}(5.98$ to 24.60$)$ & $47.89^{\star \star \star}(21.53$ to 106.52$)$ & Omitted $^{B}$ & Omitted $^{B}$ \\
\hline HIV/AIDS & - & - & - & - & 2.18 (0.82 to 5.83$)$ & $6.86^{\star}(1.35$ to 34.92$)$ & - & - \\
\hline
\end{tabular}




\begin{tabular}{|c|c|c|c|c|c|c|c|c|}
\hline & \multicolumn{2}{|l|}{$\begin{array}{l}\text { Age } 11 \text { years and below } \\
(\mathrm{N}=42623)\end{array}$} & \multicolumn{2}{|c|}{ Age $12-20$ years $(\mathrm{N}=106725)$} & \multicolumn{2}{|c|}{ Age 21-64 years $(\mathrm{N}=246640)$} & \multicolumn{2}{|c|}{ Age 65 years and above $(\mathrm{N}=15893)$} \\
\hline & $\begin{array}{l}\text { Admission } \\
\text { (RRR, 95th Cl) }\end{array}$ & $\begin{array}{l}\text { Mortality } \\
\text { (RRR, } \\
\text { 95th Cl) } \\
\end{array}$ & $\begin{array}{l}\text { Admission } \\
\text { (RRR, 95th Cl) }\end{array}$ & $\begin{array}{l}\text { Mortality } \\
\text { (RRR, 95th Cl) }\end{array}$ & $\begin{array}{l}\text { Admission } \\
\text { (RRR, 95th Cl) }\end{array}$ & $\begin{array}{l}\text { Mortality } \\
\text { (RRR, 95th Cl) }\end{array}$ & $\begin{array}{l}\text { Admission } \\
\text { (RRR, 95th Cl) }\end{array}$ & $\begin{array}{l}\text { Mortality } \\
\text { (RRR, 95th Cl) }\end{array}$ \\
\hline Lymphoma & - & - & - & - & $1.43(0.60$ to 3.43$)$ & 4.24 (0.69 to 25.95$)$ & - & - \\
\hline $\begin{array}{l}\text { Metastatic } \\
\text { cancer }\end{array}$ & - & - & - & - & $6.08^{\star \star \star}(2.22$ to 16.67$)$ & $30.32^{\star \star \star}(8.35$ to 110.18$)$ & $3.18(0.78$ to 13.04$)$ & 1.76 (0.29 to 10.55$)$ \\
\hline Solid tumour & - & - & - & - & $1.97^{\star}(1.09$ to 3.55$)$ & $5.77^{\star \star}(2.13$ to 15.59$)$ & 2.41 (0.98 to 5.91 & 5.46 (0.94 to 31.63$)$ \\
\hline $\begin{array}{l}\text { Rheumatoid } \\
\text { arthritis/collagen } \\
\text { vascular disease }\end{array}$ & - & - & 0.80 (0.21 to 3.07$)$ & Omitted $^{A}$ & $2.66^{* \star *}(1.89$ to 3.76$)$ & $2.28(0.95$ to 5.43$)$ & $3.32^{*}(1.24$ to 8.90$)$ & Omitted $^{A}$ \\
\hline Coagulopathy & - & - & $21.75^{\star \star \star}(7.70$ to 61.42$)$ & $178.62^{\star \star \star}(10.96$ to 291.11$)$ & $16.06^{\star \star *}(9.70$ to 26.57$)$ & $72.42^{\star \star *}$ (39.91 to 131.40$)$ & Omitted $^{B}$ & Omitted $^{B}$ \\
\hline Obesity & - & - & $6.29^{* \star \star}(3.95$ to 10.01$)$ & Omitted $^{A}$ & $4.96^{\star \star \star}(3.32$ to 6.27$)$ & $5.55^{\star \star \star}(3.08$ to 10.02$)$ & $5.43^{\star \star}(1.68$ to 17.54$)$ & $0.10(0.01$ to 1.37$)$ \\
\hline Weight loss & - & - & - & - & $20.51^{\star \star \star}(7.35$ to 57.18$)$ & $25.74^{\star \star \star}(7.64$ to 86.71$)$ & $19.01^{\star \star}(2.50$ to 144.65$)$ & $283.59^{\star \star \star}(17.45$ to 468.08$)$ \\
\hline $\begin{array}{l}\text { Fluid and } \\
\text { electrolyte } \\
\text { disorders }\end{array}$ & $20.75^{\star \star \star}(9.22$ to 46.70$)$ & - & $6.78^{\star \star \star}(5.70$ to 8.07$)$ & $8.91^{\star \star}(2.48$ to 31.96$)$ & $7.97^{* \star \star}(7.09$ to 8.96$)$ & $28.45^{\star \star *}(21.84$ to 37.07$)$ & $9.77^{\star \star *}(6.85$ to 13.92$)$ & $56.28^{\star \star \star}(22.19$ to 142.71$)$ \\
\hline $\begin{array}{l}\text { Blood loss or } \\
\text { deficiency } \\
\text { anaemia }\end{array}$ & $13.27^{\star \star}(2.65$ to 66.38$)$ & - & $4.17^{\star \star \star}(2.83$ to 6.15$)$ & Omitted $^{A}$ & $4.46^{* * *}$ (3.64 to 5.46$)$ & $3.34^{\star * \star}(2.22$ to 5.04$)$ & $2.64^{\star * *}(1.72$ to 4.04$)$ & 0.15 (0.01 to 4.35$)$ \\
\hline Alcohol abuse & - & - & $2.32^{\star \star \star}$ (1.94 to 2.77 ) & 1.16 (0.09 to 14.53$)$ & $2.53^{\star \star \star}$ (2.33 to 2.75$)$ & $1.75^{\star \star \star}$ (1.34 to 2.29$)$ & $2.96^{\star \star \star}(1.76$ to 4.95$)$ & 3.27 (0.71 to 15.09$)$ \\
\hline Drug abuse & - & - & $2.02^{\star \star \star}(1.77$ to 2.30$)$ & $3.02(0.59$ to 15.37$)$ & $2.37^{\star \star \star}(2.17$ to 2.59$)$ & $1.58^{\star \star}(1.17$ to 2.13$)$ & $1.71(0.96$ to 3.04$)$ & 0.59 (0.06 to 5.44$)$ \\
\hline Psychoses & - & - & $5.13^{\star \star \star}(4.48$ to 5.89$)$ & 4.46 (0.91 to 21.85$)$ & $4.44^{\star \star *}(4.00$ to 4.93$)$ & $1.42(1.00$ to 2.03$)$ & $6.41^{* * \star}(3.88$ to 10.57$)$ & 6.46 (0.84 to 49.84$)$ \\
\hline Depression & - & - & $1.71^{\star \star \star}(1.55$ to 1.88$)$ & $3.46(0.94$ to 12.70$)$ & $1.75^{\star \star \star}(1.62$ to 1.89$)$ & $1.10(0.82$ to 1.48$)$ & $1.95^{\star \star \star}(1.44$ to 2.64$)$ & 1.88 (0.79 to 4.49$)$ \\
\hline $\begin{array}{l}\text { Intentional } \\
\text { self-harm }\end{array}$ & - & - & $3.40^{\star \star \star}(3.07$ to 3.77$)$ & Omitted $^{B}$ & $3.03^{* \star *}(2.81$ to 3.26$)$ & $1.69^{\star \star \star}(1.30$ to 2.21$)$ & $4.89^{\star \star \star}$ (3.59 to 6.64$)$ & $8.57^{\star \star \star}(3.97$ to 18.49$)$ \\
\hline \multicolumn{9}{|l|}{ Calendar year } \\
\hline 2007 (vs 2006) & $0.78(0.48$ to 1.28$)$ & - & $0.92(0.80$ to 1.06$)$ & 0.95 (0.17 to 5.34$)$ & $0.99(0.88$ to to 1.11$)$ & 1.01 (0.69 to 1.49$)$ & $1.29(0.92$ to 1.81$)$ & 1.97 (0.39 to 9.87$)$ \\
\hline 2008 (vs 2006) & 0.79 (0.49 to 1.26$)$ & - & $0.79^{\star \star}(0.68$ to 0.92$)$ & 0.65 (0.07 to 5.73$)$ & $0.82^{\star *}(0.72$ to 0.94$)$ & $0.82(0.56$ to 1.21$)$ & 0.94 (0.67 to 1.32$)$ & $3.13(0.96$ to 10.19$)$ \\
\hline 2009 (vs 2006) & $0.67(0.40$ to 1.11$)$ & - & $0.84^{*}(0.72$ to 0.98$)$ & 0.30 (0.03 to 3.17$)$ & 0.87 (0.77 to 1.00$)$ & $0.58^{\star}(0.38$ to 0.88$)$ & $0.79(0.55$ to 1.13$)$ & 2.23 (0.65 to 7.64$)$ \\
\hline 2010 (vs 2006) & 0.74 (0.45 to 1.22$)$ & - & 0.88 (0.74 to 1.03$)$ & 0.56 (0.06 to 5.18$)$ & $0.83^{* \star}(0.73$ to 0.95$)$ & 0.78 (0.53 to 1.13$)$ & $1.03(0.74$ to 1.45$)$ & 2.57 (0.72 to 9.18$)$ \\
\hline $\begin{array}{l}\text { Omitted }^{\mathrm{A}} \text {, variable } \\
\text { Omitted }^{\mathrm{B}} \text {, variable } \\
{ }^{* *} \text { Statistically sigr } \\
{ }^{* *} \text { Statistically sign } \\
{ }^{*} \text { Statistically signif } \\
--, \text { Variable omitte }\end{array}$ & $\begin{array}{l}\text { omitted due to near-p } \\
\text { omitted due to near-p } \\
\text { nificant at } p<0.001 \text {. } \\
\text { ificant at } p<0.01 \text {. } \\
\text { ficant at } p<0.05 \text {. } \\
\text { d due to small sample s }\end{array}$ & $\begin{array}{l}\text { erfect asso } \\
\text { erfect asso } \\
\text { size }(n \leq 0.1\end{array}$ & $\begin{array}{l}\text { ciation with survival (ie } \\
\text { sciation with mortality (i } \\
1 \% \text { ); APAP, acetaminop }\end{array}$ & $\begin{array}{l}\text { e, OR<0.01) } \\
\text { ie, } R R R>10 \text { 000) } \\
\text { phen; ED, emergen }\end{array}$ & tmont. RRR & isk ratio. & & \\
\hline
\end{tabular}


Table 3 Invasive mechanical ventilation among APAP toxicity-related cases presenting to the ED according to age category, 2006-2010

\begin{tabular}{|c|c|c|c|c|}
\hline & $\begin{array}{l}\text { Age } 11 \text { years and } \\
\text { below }(\mathrm{N}=42623) \\
\text { Invasive mechanical } \\
\text { ventilation } \\
(\mathrm{OR}, 95 \text { th } \mathrm{Cl})\end{array}$ & $\begin{array}{l}\text { Age } 12-20 \text { years } \\
\text { ( } \mathrm{N}=106725) \\
\text { Invasive mechanical } \\
\text { ventilation } \\
(\mathrm{OR} \text {, 95th } \mathrm{Cl})\end{array}$ & $\begin{array}{l}\text { Age } 21-64 \text { years } \\
\text { ( } \mathrm{N}=246640) \\
\text { Invasive mechanical } \\
\text { ventilation } \\
(\mathrm{OR} \text {, 95th } \mathrm{Cl})\end{array}$ & $\begin{array}{l}\text { Age } 65 \text { years and } \\
\text { above ( } \mathrm{N}=15 \text { 893) } \\
\text { Invasive mechanical } \\
\text { ventilation } \\
\text { (OR, 95th } \mathrm{Cl})\end{array}$ \\
\hline \multicolumn{5}{|l|}{ Patient characteristics } \\
\hline Age & - & $1.26^{*}(1.16$ to 1.36$)$ & $1.03^{*}(1.02$ to 1.03$)$ & $0.96^{*}(0.95$ to 0.98$)$ \\
\hline Female sex & - & $0.46^{*}(0.35$ to 0.60$)$ & $0.85^{*}(0.78$ to 0.92$)$ & $1.12(0.84$ to 1.50$)$ \\
\hline \multicolumn{5}{|c|}{ Payer (vs commercial insurance) } \\
\hline Medicare & - & $0.62(0.15$ to 2.58$)$ & $0.82^{*}(0.72$ to 0.95$)$ & 1.03 (0.37 to 2.84$)$ \\
\hline Medicaid & - & 0.92 (0.67 to 1.28$)$ & 1.05 (0.94 to 1.17$)$ & $1.52(0.52$ to 4.45$)$ \\
\hline Other & - & 1.01 (0.71 to 1.43$)$ & $0.78^{*}(0.70$ to 0.87$)$ & $0.46(0.12$ to 1.79$)$ \\
\hline \multicolumn{5}{|c|}{ Income quartile (vs lowest) } \\
\hline 2nd quartile & - & $0.92(0.63$ to 1.35$)$ & $1.10(0.99$ to 1.23$)$ & $1.12(0.76$ to 1.65$)$ \\
\hline 3rd quartile & - & $0.92(0.62$ to 1.37$)$ & $1.23^{*}(1.08$ to 1.39$)$ & 1.01 (0.69 to 1.48$)$ \\
\hline 4th quartile & - & $0.92(0.61$ to 1.40$)$ & 1.08 (0.95 to 1.24$)$ & 0.91 (0.58 to 1.41$)$ \\
\hline Rural residence & - & 1.96 (0.97 to 3.99$)$ & 1.25 (1.01 to 1.55$)$ & 1.07 (0.55 to 2.10$)$ \\
\hline \multicolumn{5}{|l|}{ Hospital characteristics } \\
\hline Rural location & - & $0.38^{*}(0.16$ to 0.91$)$ & $0.61^{\star}(0.47$ to 0.77$)$ & 0.57 (0.26 to 1.26$)$ \\
\hline Teaching facility & - & $1.51^{*}(1.12$ to 2.03$)$ & 1.10 (0.98 to 1.22$)$ & $1.27(0.95$ to 1.71$)$ \\
\hline \multicolumn{5}{|c|}{ Region (vs Northeast) } \\
\hline Midwest & - & $0.79(0.53$ to 1.18$)$ & $0.87(0.75$ to 1.01$)$ & $0.88(0.56$ to 1.36$)$ \\
\hline South & - & 0.77 (0.51 to 1.17$)$ & $0.99(0.86$ to 1.15$)$ & $0.90(0.59$ to 1.36$)$ \\
\hline West & - & $0.72(0.45$ to 1.13$)$ & $0.94(0.81$ to 1.08$)$ & $0.90(0.57$ to 1.42$)$ \\
\hline \multicolumn{5}{|l|}{ Clinical characteristics } \\
\hline $\begin{array}{l}\text { Congestive heart } \\
\text { failure }\end{array}$ & - & - & $1.61^{*}(1.17$ to 2.21$)$ & 1.39 (0.86 to 2.25$)$ \\
\hline Valvular disease & - & $8.31^{*}(1.91$ to 36.10$)$ & $1.12(0.78$ to 1.62$)$ & 0.77 (0.35 to 1.73$)$ \\
\hline $\begin{array}{l}\text { Pulmonary circulation } \\
\text { disorders }\end{array}$ & - & - & $2.66^{\star}(1.46$ to 4.86$)$ & 0.83 (0.27 to 2.53$)$ \\
\hline $\begin{array}{l}\text { Peripheral vascular } \\
\text { disorders }\end{array}$ & - & - & 1.25 (0.70 to 2.21$)$ & 1.06 (0.56 to 2.02$)$ \\
\hline $\begin{array}{l}\text { Hypertension with } \\
\text { complications }\end{array}$ & - & $2.48^{*}(1.11$ to 5.56$)$ & $0.86(0.54$ to 1.36$)$ & 2.01 (0.91 to 4.45$)$ \\
\hline Paralysis & - & Omitted $^{A}$ & $1.95^{*}(1.29$ to 2.94$)$ & $0.26(0.03$ to 2.25$)$ \\
\hline $\begin{array}{l}\text { Other neurological } \\
\text { disorders }\end{array}$ & - & $7.11^{*}(5.00$ to 10.11$)$ & $1.88^{*}(1.66$ to 2.13$)$ & $1.10(0.76$ to 1.60$)$ \\
\hline $\begin{array}{l}\text { Chronic pulmonary } \\
\text { disease }\end{array}$ & - & $1.79^{\star}$ (1.09 to 2.92$)$ & $1.34^{\star}(1.18$ to 1.51$)$ & $1.75^{\star}$ (1.26 to 2.44$)$ \\
\hline $\begin{array}{l}\text { Diabetes with } \\
\text { complications }\end{array}$ & - & 0.79 (0.13 to 4.81$)$ & 0.91 (0.56 to 1.46$)$ & $0.62(0.21$ to 1.79$)$ \\
\hline Hypothyroidism & - & $0.87(0.25$ to 3.09$)$ & $0.91(0.75$ to 1.11$)$ & $0.56^{*}(0.35$ to 0.89$)$ \\
\hline Renal failure & - & 1.78 (0.18 to 17.95$)$ & 1.25 (0.82 to 1.92$)$ & $0.42(0.19$ to 0.94$)$ \\
\hline Liver disease & - & $2.49(0.44$ to 14.03$)$ & $2.23^{*}(1.77$ to 2.81$)$ & $2.47^{\star}(1.17$ to 5.21$)$ \\
\hline AIDS & - & - & $2.11^{*}(1.23$ to 3.60$)$ & - \\
\hline Lymphoma & - & - & $1.93(0.84$ to 4.40$)$ & - \\
\hline Metastatic cancer & - & - & $1.68(0.79$ to 3.59$)$ & 0.47 (0.09 to 2.47$)$ \\
\hline Solid tumour & - & - & 0.68 (0.32 to 1.44$)$ & 0.27 (0.06 to 1.22$)$ \\
\hline $\begin{array}{l}\text { Rheumatoid arthritis/ } \\
\text { collagen vascular } \\
\text { disease }\end{array}$ & - & Omitted $^{A}$ & $1.59^{*}(1.18$ to 2.14$)$ & 0.48 (0.18 to 1.25$)$ \\
\hline Coagulopathy & - & $2.58^{*}(1.13$ to 5.89$)$ & $2.48^{*}(2.10$ to 2.94$)$ & $2.17^{*}(1.27$ to 3.70$)$ \\
\hline Obesity & - & 0.98 (0.29 to 3.29$)$ & 1.11 (0.91 to 1.36$)$ & $0.49(0.17$ to 1.35$)$ \\
\hline Weight loss/cachexia & - & - & $1.90^{*}(1.43$ to 2.53$)$ & $1.92^{*}(1.13$ to 3.28$)$ \\
\hline $\begin{array}{l}\text { Fluid and electrolyte } \\
\text { disorders }\end{array}$ & - & $5.84^{*}(4.26$ to 8.00$)$ & $4.08^{*}(3.75$ to 4.43$)$ & $2.26^{*}(1.71$ to 3.00$)$ \\
\hline $\begin{array}{l}\text { Blood loss or } \\
\text { deficiency anaemia }\end{array}$ & - & $2.07^{*}(1.33$ to 3.97$)$ & $1.36^{\star}(1.17$ to 1.58$)$ & $1.15(0.79$ to 1.67$)$ \\
\hline
\end{tabular}


Table 3 Continued

\begin{tabular}{|c|c|c|c|c|}
\hline & $\begin{array}{l}\text { Age } 11 \text { years and } \\
\text { below }(\mathrm{N}=42623) \\
\text { Invasive mechanical } \\
\text { ventilation } \\
(\mathrm{OR}, 95 \text { th } \mathrm{Cl})\end{array}$ & $\begin{array}{l}\text { Age } 12-20 \text { years } \\
(\mathrm{N}=106725) \\
\text { Invasive mechanical } \\
\text { ventilation } \\
(\mathrm{OR}, 95 \text { th } \mathrm{Cl})\end{array}$ & $\begin{array}{l}\text { Age } 21-64 \text { years } \\
\text { ( } \mathrm{N}=246640) \\
\text { Invasive mechanical } \\
\text { ventilation } \\
(\mathrm{OR}, 95 \text { th } \mathrm{Cl})\end{array}$ & $\begin{array}{l}\text { Age } 65 \text { years and } \\
\text { above }(\mathrm{N}=15893) \\
\text { Invasive mechanical } \\
\text { ventilation } \\
\text { (OR, 95th } \mathrm{Cl})\end{array}$ \\
\hline Alcohol abuse & - & $1.90^{*}(1.34$ to 2.71$)$ & $1.26^{\star}(1.16$ to 1.37$)$ & $0.78(0.47$ to 1.29$)$ \\
\hline Drug abuse & - & $1.50^{*}(1.10$ to 2.04$)$ & $1.16^{*}(1.06$ to 1.27$)$ & $0.62(0.32$ to 1.18$)$ \\
\hline Psychoses & - & $1.62^{*}(1.12$ to 2.35$)$ & $1.51^{*}(1.37$ to 1.67$)$ & $1.28(0.91$ to 1.80$)$ \\
\hline Depression & - & $1.10(0.81$ to 1.49$)$ & $1.04(0.95$ to 1.14$)$ & $0.87(0.61$ to 1.23$)$ \\
\hline Intentional self-harm & - & $1.34(0.96$ to 1.87$)$ & $1.49^{*}(1.35$ to 1.63$)$ & $2.42^{*}(1.80$ to 3.25$)$ \\
\hline \multicolumn{5}{|l|}{ Calendar year } \\
\hline 2007 (vs 2006) & - & $0.99(0.64$ to 1.55$)$ & $0.99(0.86$ to 1.14$)$ & $1.02(0.63$ to 1.67$)$ \\
\hline 2008 (vs 2006) & - & $0.98(0.64$ to 1.51$)$ & 1.05 (0.92 to 1.20$)$ & $0.81(0.53$ to 1.25$)$ \\
\hline 2009 (vs 2006) & - & $0.94(0.60$ to 1.48$)$ & $0.92(0.81$ to 1.05$)$ & 1.07 (0.69 to 1.65$)$ \\
\hline 2010 (vs 2006) & - & $0.96(0.63$ to 1.46$)$ & $0.95(0.83$ to 1.10$)$ & $1.12(0.73$ to 1.71$)$ \\
\hline
\end{tabular}

deficiency anaemia, alcohol abuse, drug abuse and psychoses were associated with increased odds $(p<0.028)$ among 12-20 and 21-64 years age groups. Several factors had near-perfect associations with invasive mechanical ventilation within the 12-20 years age group. Notably, over time, no consistent change in odds of requiring invasive mechanical ventilation across years was observed from 2006.

\section{Multivariable analysis: charges, length of stay}

The multivariable analysis of charges and length of stay (table 4) indicated varying associations with these economic outcomes. Suggestive of greater intensities of care required across all age categories, consistently significant increased charges and lengths of stay were associated with liver disease $(p<0.036$ for charges, $p<0.024$ for length of stay), while weight loss/cachexia and coagulopathy were significant across age groups 21-64 and $\geq 65$ years; HIV/AIDS was significant in the 21-64 years age category. Increased charges alone were associated with intentional self-harm and most Elixhauser comorbidities: heart failure; hypertension with complications; other neurological disorders; coagulopathy; fluid and electrolyte disorders; blood loss or deficiency anaemia; alcohol abuse; psychoses; and depression $(p<0.036)$. No consistent change across age categories was noted over time for either charges or length of stay.

\section{DISCUSSION}

This investigation examined nationally representative cases of APAP toxicity-associated ED visits in the USA from 2006 to 2010, assessing the independent associations between outcomes of inpatient admission, mortality, required use of invasive mechanical ventilation, charges and lengths of stay based on several patient, clinical and hospital characteristics. Overall, 411881 ED visits were observed (82 376 per year), equating to $27.10 \mathrm{ED}$ visits per 100000 US population annually, and the summing up to a national bill of $\$ 1.06$ billion per year (US $\$ 2014$ ). Some $37.2 \%$ cases were treated-and-released directly from the ED (30 783 per year), $45.5 \%$ were admitted to the inpatient setting (37 877 per year) and $0.6 \%$ involved death (484 per year). The number of ED presentations did not appreciably change over time, decreasing by $<2 \%$ from 2006 to $2010(n=1351)$, though representing an overall change from 27.15 to 25.78 visits per 100000 US population annually.

Comparatively, Nourjah et a $\overline{\bar{l}}$ estimated that attributable APAP overdoses from 1993 to 1999 were lower than aforementioned findings, with approximately $56000 \mathrm{ED}$ visits, 26000 hospitalisations and 458 deaths per year; $\mathrm{Li}$ and $\mathrm{Martin}^{8}$ also reported a decrease in rates from 2001 to 2007 to slightly less than $45000 \mathrm{ED}$ visits per year. From 1993 to $1999, \mathrm{Li}$ and $\operatorname{Martin}^{8}$ found a lower number of ED visits, at 21.03 visits per 100000 persons per year and decreasing to 15.21 from 2000 to 2007 . It is critical to note that Nourjah et $a l,{ }^{5}$ and $\mathrm{Li}$ and Martin ${ }^{8}$ utilised different national data than the present study, data that have explicitly been identified with a discrepancy in the number of cases associated with intentional APAP overdose-related visits; however, unintentional poisonings appeared to be similar across various data sources. ${ }^{6}{ }^{7}$ Manthripragada et at ${ }^{6}$ presented results illustrating differences present within nationally representative studies, in which the number of APAP toxicity-associated ED visits may be potentially underestimated by perhaps one-third to one-half. More closely parallel to the present study, Budnitz et $a l^{7}$ reported 78414 annual ED visits associated with APAP overdoses from 2005 to 2006 using data from the National Electronic Injury Surveillance System (NEISS), while Manthripragada et at found an age-adjusted rate of 13.9 hospitalisations per 100000 US population from 2000 to 
Table 4 Total charges and inpatient length of stay among APAP toxicity-related cases presenting to the ED according to age category, 2006-2010

\begin{tabular}{|c|c|c|c|c|c|c|c|c|}
\hline & \multicolumn{2}{|c|}{ Age 11 years and below ( $N=42623)$} & \multicolumn{2}{|c|}{ Age $12-20$ years $(\mathrm{N}=106725)$} & \multicolumn{2}{|c|}{ Age $21-64$ years $(\mathrm{N}=246640)$} & \multicolumn{2}{|c|}{ Age 65 years and above $(\mathrm{N}=15893)$} \\
\hline & $\begin{array}{l}\text { Charges (exp(b), } \\
\text { 95th Cl) }\end{array}$ & LoS (IR, 95th Cl) & $\begin{array}{l}\text { Charges (exp(b), } \\
\text { 95th Cl) }\end{array}$ & LoS (IR, 95th Cl) & $\begin{array}{l}\text { Charges (exp(b), } \\
\text { 95th Cl) }\end{array}$ & LoS (IR, 95th Cl) & $\begin{array}{l}\text { Charges }(\exp (b), \\
\text { 95th Cl) }\end{array}$ & LoS (IR, 95th Cl) \\
\hline \multicolumn{9}{|l|}{ Patient characteristics } \\
\hline Age & $1.04^{*}(1.01$ to 1.07$)$ & $1.03(0.99$ to 1.07$)$ & $1.05^{*}(1.04$ to 1.06$)$ & 0.99 (0.98 to 1.01$)$ & $1.01^{*}(1.01$ to 1.01$)$ & $1.01^{*}(1.01$ to 1.01$)$ & $1.00(1.00$ to 1.01$)$ & $1.01(1.00$ to 1.01$)$ \\
\hline Female sex & 0.94 (0.86 to 1.02$)$ & $1.07(0.88$ to 1.31$)$ & 0.97 (0.93 to 1.01$)$ & $1.00(0.95$ to 1.05$)$ & $0.96^{*}(0.93$ to 0.98$)$ & $0.97^{*}(0.94$ to 0.99$)$ & 0.91 (0.83 to 1.01$)$ & 0.94 (0.85 to 1.03$)$ \\
\hline \multicolumn{9}{|l|}{ Payer (vs commercial) } \\
\hline Medicare & - & - & 0.93 (0.65 to 1.33$)$ & $1.55(0.90$ to 2.65$)$ & $0.98(0.94$ to 1.03$)$ & $1.01(0.96$ to 1.06$)$ & $1.14(0.83$ to 1.56$)$ & 1.18 (0.81 to 1.72$)$ \\
\hline Medicaid & $0.81^{*}(0.71$ to 0.92$)$ & $0.96(0.79$ to 1.16$)$ & $0.92^{*}(0.87$ to 0.96$)$ & $0.94^{*}(0.89$ to 0.98$)$ & $0.96^{*}(0.93$ to 0.98$)$ & $0.86^{*}(0.83$ to 0.91$)$ & $0.92(0.65$ to 1.31$)$ & $1.12(0.74$ to 1.69$)$ \\
\hline Other & 0.89 (0.71 to 1.05$)$ & $1.08(0.75$ to 1.55$)$ & $0.87^{*}(0.82$ to 0.92$)$ & $0.92^{*}(0.87$ to 0.98$)$ & 0.97 (0.94 to 1.01$)$ & $0.94^{*}(0.90$ to 0.98$)$ & $0.56^{*}(0.36$ to 0.86$)$ & $0.93(0.58$ to 1.49$)$ \\
\hline \multicolumn{9}{|l|}{ Income quartile (vs lowest) } \\
\hline 2nd quartile & 1.06 (0.95 to 1.18$)$ & $1.27(0.97$ to 1.66$)$ & $1.04(0.98$ to 1.10$)$ & $1.05(0.99$ to 1.11$)$ & $1.01(0.97$ to 1.04$)$ & 0.99 (0.95 to 1.02$)$ & $0.98(0.86$ to 1.11$)$ & $0.99(0.88$ to 1.12$)$ \\
\hline 3rd quartile & $1.06(0.88$ to 1.28$)$ & $1.33(0.95$ to 1.88$)$ & $1.03(0.97$ to 1.10$)$ & 1.05 (0.98 to 1.12$)$ & $1.01(0.96$ to 1.06$)$ & $1.00(0.95$ to 1.05$)$ & 0.99 (0.87 to 1.14$)$ & $0.92(0.81$ to 1.04$)$ \\
\hline 4th quartile & 0.95 (0.79 to 1.14$)$ & $1.28(0.97$ to 1.68$)$ & 1.03 (0.95 to 1.12$)$ & $1.00(0.93$ to 1.07$)$ & $1.09^{*}(1.02$ to 1.17$)$ & 0.99 (0.94 to 1.04$)$ & $1.13(0.96$ to 1.33$)$ & $0.95(0.85$ to 1.09$)$ \\
\hline Rural residence & $1.19(0.97$ to 1.45$)$ & $1.12(0.71$ to 1.75$)$ & $1.00(0.92$ to 1.08$)$ & 0.96 (0.86 to 1.07$)$ & $1.03(0.96$ to 1.10$)$ & $1.01(0.94$ to 1.09$)$ & 0.93 (0.75 to 1.14$)$ & $1.06(0.88$ to 1.27$)$ \\
\hline \multicolumn{9}{|l|}{ Hospital characteristics } \\
\hline Rural location & $0.68^{*}(0.55$ to 0.87$)$ & $0.86(0.52$ to 1.43$)$ & $0.73^{*}(0.66$ to 0.81$)$ & $0.80^{*}(0.71$ to 0.91$)$ & $0.66^{*}$ (0.60 to 0.72$)$ & $0.76^{*}(0.69$ to 0.83$)$ & $0.52^{*}(0.42$ to 0.66$)$ & $0.67^{\star}(0.54$ to 0.82$)$ \\
\hline Teaching facility & $1.28^{*}(1.10$ to 1.49$)$ & $1.23(0.98$ to 1.54$)$ & $1.14^{*}$ (1.06 to 1.24$)$ & $1.03(0.96$ to 1.10$)$ & $1.06(0.99$ to 1.13$)$ & $1.09^{*}(1.05$ to 1.15$)$ & 0.95 (0.84 to 1.07$)$ & $1.02(0.93$ to 1.13$)$ \\
\hline \multicolumn{9}{|l|}{ Region (vs Northeast) } \\
\hline Midwest & $0.74^{\star}(0.64$ to 0.87$)$ & $0.72^{*}(0.55$ to 0.95$)$ & $0.78^{\star}(0.71$ to 0.86$)$ & $0.83^{*}(0.76$ to 0.90$)$ & $0.71^{*}(0.65$ to 0.78$)$ & $0.79^{*}(0.73$ to 0.85$)$ & $0.72^{*}(0.61$ to 0.85$)$ & $0.74^{\star}(0.66$ to 0.83$)$ \\
\hline South & 0.89 (0.76 to 1.05$)$ & 0.91 (0.68 to 1.23 ) & $0.88^{*}(0.79$ to 0.98$)$ & $0.91^{*}(0.85$ to 0.97$)$ & $0.87^{\star}(0.79$ to 0.97$)$ & $0.90^{*}(0.85$ to 0.96$)$ & $0.88(0.75$ to 1.04$)$ & $0.85^{*}(0.75$ to 0.96$)$ \\
\hline West & $0.35^{*}(0.27$ to 0.45$)$ & $0.71^{*}(0.54$ to 0.95$)$ & $0.64^{*}(0.57$ to 0.73$)$ & $0.76^{*}(0.71$ to 0.82$)$ & $0.78^{\star}$ (0.70 to 0.86$)$ & $0.82^{*}(0.77$ to 0.87$)$ & 0.85 (0.71 to 1.02$)$ & $0.74^{\star}(0.65$ to 0.83$)$ \\
\hline \multicolumn{9}{|l|}{ Clinical characteristics } \\
\hline Congestive heart failure & - & - & - & - & $1.52^{*}(1.30$ to 1.78$)$ & $1.31^{*}(1.14$ to 1.50$)$ & $1.39^{\star}(1.23$ to 1.59$)$ & $1.25^{\star}(1.12$ to 1.40$)$ \\
\hline Valvular disease & - & - & $1.36(0.94$ to 1.96$)$ & 0.99 (0.68 to 1.44$)$ & $1.42^{*}(1.23$ to 1.63$)$ & $1.06(0.95$ to 1.18$)$ & $1.56^{\star}(1.26$ to 1.94$)$ & $1.08(0.91$ to 1.29$)$ \\
\hline $\begin{array}{l}\text { Pulmonary circulation } \\
\text { disorders }\end{array}$ & - & - & - & - & $1.90^{*}(1.45$ to 2.47$)$ & $1.45^{\star}(1.19$ to 1.77$)$ & 1.27 (0.89 to 1.81$)$ & $1.10(0.79$ to 1.54$)$ \\
\hline $\begin{array}{l}\text { Peripheral vascular } \\
\text { disorders }\end{array}$ & - & - & - & - & $1.81^{*}(1.47$ to 2.23$)$ & $1.40^{*}(1.12$ to 1.74$)$ & 1.18 (0.98 to 1.42$)$ & $1.01(0.85$ to 1.19$)$ \\
\hline $\begin{array}{l}\text { Hypertension with } \\
\text { complications }\end{array}$ & - & - & $1.51^{\star}(1.28$ to 1.79$)$ & $1.35^{*}(1.17$ to 1.56$)$ & $1.43^{\star}(1.19$ to 1.71$)$ & $1.23^{*}(1.05$ to 1.45$)$ & $1.50^{*}(1.23$ to 1.84$)$ & 1.17 (0.99 to 1.37$)$ \\
\hline Paralysis & - & - & 1.79 (1.03 to 3.09$)$ & $1.02(0.70$ to 1.48$)$ & $1.60^{*}(1.32$ to 1.94$)$ & $1.39^{*}(1.19$ to 1.63$)$ & $1.94^{*}(1.12$ to 3.36$)$ & 2.24 (1.08 to 4.62$)$ \\
\hline $\begin{array}{l}\text { Other neurological } \\
\text { disorders }\end{array}$ & $7.00^{*}(2.80$ to 17.49$)$ & 1.41 (1.02 to 1.96$)$ & $1.61^{\star}(1.45$ to 1.78$)$ & 1.05 (0.94 to 1.17$)$ & $1.29^{*}(1.24$ to 1.34$)$ & 1.00 (0.97 to 1.04$)$ & $1.15^{*}(1.03$ to 1.29$)$ & $1.01(0.90$ to 1.13$)$ \\
\hline Chronic pulmonary disease & 0.98 (0.80 to 1.20$)$ & 0.81 (0.61 to 1.08$)$ & $1.18^{\star}(1.11$ to 1.26$)$ & 0.97 (0.91 to 1.04$)$ & $1.20^{*}(1.15$ to 1.26$)$ & $1.02(0.98$ to 1.07$)$ & $1.37^{\star}(1.23$ to 1.52$)$ & $1.03(0.94$ to 1.12$)$ \\
\hline Diabetes with complications & - & - & $1.02(0.86$ to 1.20$)$ & $0.90(0.74$ to 1.11$)$ & $1.27^{\star}(1.11$ to 1.45$)$ & 1.07 (0.95 to 1.22$)$ & $1.60(0.97$ to 2.66$)$ & $1.07(0.79$ to 1.46$)$ \\
\hline Hypothyroidism & - & - & 1.31 (1.00 to 1.72$)$ & $1.39^{*}(1.08$ to 1.79$)$ & $1.23^{*}(1.15$ to 1.31$)$ & $1.01(0.94$ to 1.08$)$ & $1.12(1.00$ to 1.25$)$ & 0.89 (0.81 to 0.99$)$ \\
\hline Renal failure & - & - & 1.41 (0.84 to 2.37$)$ & 0.88 (0.51 to 1.51$)$ & $1.43^{*}(1.23$ to 1.67$)$ & $1.16(1.00$ to 1.33$)$ & $1.03(0.82$ to 1.29$)$ & 0.99 (0.80 to 1.22$)$ \\
\hline Liver disease & - & - & $1.76^{\star}(1.30$ to 2.39$)$ & $1.53^{*}(1.15$ to 2.03$)$ & $2.00^{*}$ (1.80 to 2.23$)$ & $1.52^{*}(1.39$ to 1.67$)$ & $2.34^{*}(1.66$ to 3.31$)$ & $1.52^{*}(1.19$ to 1.95$)$ \\
\hline HIV/AIDS & - & - & - & - & $1.56^{*}(1.18$ to 2.06$)$ & $1.30^{*}(1.12$ to 1.52$)$ & - & - \\
\hline Lymphoma & - & - & - & - & $1.16(0.86$ to 1.57$)$ & $1.02(0.78$ to 1.34$)$ & - & - \\
\hline Metastatic cancer & - & - & - & - & $1.64^{*}(1.16$ to 2.31$)$ & $1.48^{*}(1.07$ to 2.03$)$ & $1.38(0.89$ to 2.15$)$ & $1.06(0.64$ to 1.76$)$ \\
\hline Solid tumour & - & - & - & - & 1.23 (0.97 to 1.56$)$ & 1.12 (0.92 to 1.36$)$ & $1.02(0.84$ to 1.24$)$ & 0.88 (0.72 to 1.08$)$ \\
\hline $\begin{array}{l}\text { Rheumatoid arthritis/ } \\
\text { collagen vascular disease }\end{array}$ & - & - & 0.71 (0.38 to 1.32$)$ & 0.84 (0.41 to 1.72$)$ & $1.34^{*}(1.21$ to 1.49$)$ & $1.12(1.00$ to 1.25$)$ & $1.33^{*}(1.07$ to 1.64$)$ & $1.02(0.83$ to 1.25$)$ \\
\hline Coagulopathy & - & - & $3.04^{\star}(2.46$ to 3.78$)$ & $1.98^{*}(1.63$ to 2.41$)$ & $2.08^{*}$ (1.91 to 2.26$)$ & $1.48^{*}(1.39$ to 1.59$)$ & $1.54^{\star}(1.26$ to 1.89$)$ & $1.12(0.92$ to 1.36$)$ \\
\hline Obesity & - & - & $1.58^{\star}(1.40$ to 1.79$)$ & $1.14(1.01$ to 1.28$)$ & $1.39^{*}(1.31$ to 1.48$)$ & 1.11 (1.01 to 1.22$)$ & 1.18 (0.96 to 1.44$)$ & 0.95 (0.76 to 1.20$)$ \\
\hline Weight loss/cachexia & - & - & - & - & $1.99^{*}$ (1.63 to 2.42$)$ & $1.83^{*}(1.58$ to 2.13$)$ & $1.68^{*}(1.32$ to 2.16$)$ & $1.58^{*}(1.31$ to 1.89$)$ \\
\hline $\begin{array}{l}\text { Fluid and electrolyte } \\
\text { disorders }\end{array}$ & $6.46^{*}(3.26$ to 12.81$)$ & $1.93^{\star}$ (1.34 to 2.80$)$ & $1.95^{\star}(1.84$ to 2.08$)$ & 1.04 (0.99 to 1.09$)$ & $1.82^{*}(1.76$ to 1.88$)$ & $1.16^{*}(1.13$ to 1.20$)$ & $1.81^{*}$ (1.62 to 2.02$)$ & $1.18^{*}(1.08$ to 1.28$)$ \\
\hline
\end{tabular}
disorders 


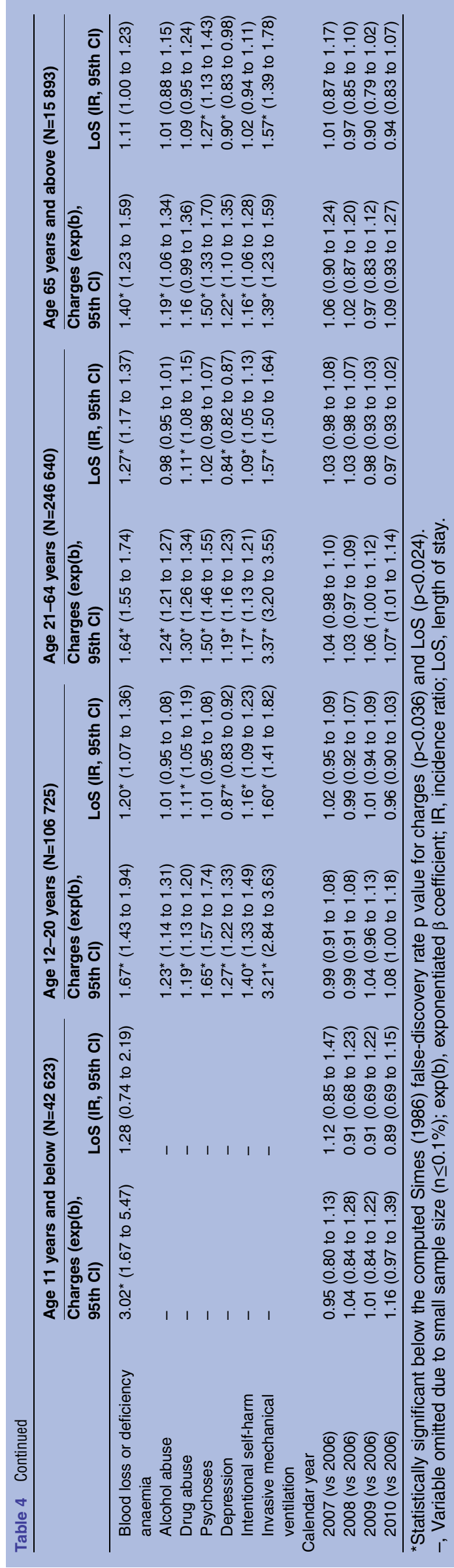

2006. Also consistent with the current work, a decrease in the number of ED visits or hospitalisations over time relating to APAP overdose was not observed. ${ }^{6}$

The average age in the present study was 29.3 years, with $60.0 \%$ of ED visits occurring across the 21-64-year age group. Though constituting $16.2 \%$ and $11.1 \%$ of the US population, some $10.3 \%$ and $25.9 \%$ of cases, respectively, involved persons $0-11$ and 12-20 years of age. Furthermore, ED presentations exceeding 50 visits per 100000 persons per year were noted from ages 1 to 2 and 15-22 years, peaking at over 70 per 100000 specifically at age 2 years and ages 16-18 years. Broader surveillance figures suggest that age-adjusted overall non-fatal injuries relating to poisoning of any type was 36.14 per 100000 in 2013, though the crude rate for ages $1-2$ years is 12.27 per 100000 and is 35.79 per 100000 for ages $15-22$ years. ${ }^{23}$ Prior investigations suggest a substantially large number of APAP toxicity-related ED visits occur among young children, adolescents and young adults; $\mathrm{Li}$ and Martin ${ }^{8}$ reported 72.42 visits per 100000 for cases under 5 years of age, 61.91 per 100000 for ages 15-17 years and 40.92 per 100000 for ages 18-24 years. ${ }^{72425}$ Budnitz $e t a l^{7}$ found that $13.4 \%$ of APAP overdose ED visits were attributed to unsupervised ingestions by children aged 5 years and under, a finding which has been observed across other work. ${ }^{26-28}$ Others have found higher risks for APAP toxicity-related ED visits due, in part, to single ingredient unintentional overdose or high use of APAP products. ${ }^{24} 2528$

A majority of cases in the current work involved the female sex $(65.5 \%)$ and intentional self-harm (58.4\%): these were highest in the 12-20 years age category: $74.8 \%$ female and $71.4 \%$ intentional self-harm. Similar to Li and Bradly (2011), behavioural and mental health comorbidities were common and represented the largest proportions of Elixhauser comorbidities, including depression (25.0\%), psychoses $(15.3 \%)$, drug abuse $(15.6 \%)$ and alcohol abuse $(13.7 \%)$. Notably, these comorbid conditions were also associated with increased relative risk of admission and likelihood of charges almost entirely across all age categories $\geq 12$ years within the multivariable analyses. ${ }^{8}$ Over most age categories $\geq 12$ years, intentional self-harm was generally associated with increased odds of admission, mortality, requirement of invasive mechanical ventilation, charges and length of stay. Budnitz et $a l^{7}$ reported that $69.8 \%$ of $\mathrm{ED}$ visits involving APAP overdoses from 2006 to 2007 were associated with self-directed violence, peaking among those between 15 and 24 years of age, with $75 \%$ ultimately resulting in either psychiatric or inpatient hospitalisations. Surveillance data also suggest that one-quarter of all ED cases for intentional poisoning involve APAP. ${ }^{23}$ Budnitz $e t a l^{7}$ also noted that females had the highest rates of intentional self-harm, especially as adolescents or young adults. It has been noted in prior work that suicide attempts via toxic medication ingestion is more frequently observed among adolescents and often associated with impulsivity, of which toxic APAP ingestion 
has been classified. ${ }^{7}$ 29-31 Importantly, Manthripragada et at $t^{6}$ emphasised that discerning whether self-harm was intentional versus accidental remains challenging to ascertain via secondary data, potentially resulting in the misclassification of cases involving non-accidental poisoning via supplementary ICD-9 codes (ie, E-codes) or differences in hospital reporting requirements. ${ }^{32} 33$

Results of the multivariable analysis indicated that rural patient residence (municipalities $\leq 50000$ persons) was associated with a higher odds of admission across age categories $<65$ years. Among age categories $\geq 12$ years, an increased relative risk of admission and mortality was associated with liver disease, coagulopathy, fluid and electrolyte disorders, and weight loss/cachexia. With some exceptions, increased odds of invasive mechanical ventilation, charges and lengths of stay were also observed with these comorbidities as well. $\mathrm{Li}$ and Martin (2011) reported a $8.62 \times$ higher odds of ED visits attributed to APAP toxicity with alcohol abuse or dependence $(p<0.001)$; findings from the current work also suggest over a $2 \times$ higher relative risk of admission (age categories $\geq 12$ years), a $1.75 \times$ higher relative risk of mortality (ages 21-64 years), over $1.19 \times$ higher charges (age categories $\geq 12$ years), and $1.26 \times$ or greater odds of invasive mechanical ventilation (ages 12-20 and 21-64 years). Paediatric admission cases of age $<12$ years were associated with other neurological disorders, fluid and electrolyte disorders, and blood loss or deficiency anaemia; Budnitz et al ${ }^{7}$ reported that most of the unsupervised ingestions of APAP were observed among children aged $<6$ years, typically treated-and-released from the ED setting via gastric decontamination or $\mathrm{N}$-acetyl cysteine (NAS) treatment.

Although findings from this study provide updated information concerning the burden of APAP-related ED visits in the USA, some important study limitations exist. While similar coding algorithms were used, as in other retrospective studies, to identify APAP-toxicity cases, no specific categorisation was present that may have classified cases as being unsupervised ingestions or therapeutic misadventures (eg, overuse, medication errors); as per the type of APAP product consumed (eg, single-agent, combination products, tablets, liquid), and according to the estimated amount ingested or serum levels observed..$^{5-8} 15{ }^{16}$ In this context, Budnitz et $a l^{7}$ reported that $13.4 \%$ of APAP toxicity-related ED visits were attributed to unsupervised ingestions and $16.7 \%$ involved therapeutic misadventures, with slightly over half involving overuse of agents versus dosage confusion or APAP overingestion from multiple source products. The use of NAS or gastric decontamination was also not consistently captured within the data set, nor was a designation of acute liver injury directly attributable to APAP toxicity. ${ }^{6}$ Generalisations of findings beyond acute care settings are not appropriate to estimate the prevalence of APAP poisoning in the USA, as cases presenting to poison centres or within ambulatory practices are not captured. At the time of this study's initiation, the 2006-2010 time frame reflected the entirety of
HCUP NEDS data; the complex process of collecting, integrating, validating and distributing data of this nature typically takes 2 years. ${ }^{14}$ As such, given the time horizon of this study and available data, continued work is warranted to study the impact of more recent APAP dose limitations established by the FDA in addition to studies focusing directly on consumer perceptions, attitudes, beliefs, knowledge and health literacy. ${ }^{9-13} 34-45$

\section{CONCLUSION}

This nationally representative study of ED visits in the USA highlights a substantial public health impact of APAP toxicity-related cases from 2006 to 2010. Overall, 82376 cases per year were observed, summing up to a national bill of $\$ 1.06$ billion. The ED visit average rate across all ages was 27.10 ED visits per 100000 US population, exceeding 70 per 100000 for age 2 years and ages $16-18$ years. After controlling for numerous factors, no consistent temporal change was observed during the 5-year time horizon concerning outcomes of admission, mortality, invasive mechanical ventilation, charges or length of stay.

\section{Author affiliations}

${ }^{1}$ The University of Arizona, Center for Health Outcomes and

PharmacoEconomic Research, College of Pharmacy, Tucson, Arizona, USA

${ }^{2}$ Currently at The Department of Clinical Pharmacy, King Abdulaziz University

College of Pharmacy, Jeddah, Saudi Arabia

${ }^{3}$ The University of Arizona, Mel and Enid Zuckerman College of Public Health, Tucson, Arizona, USA

${ }^{4}$ Currently at The University of Oklahoma Health Sciences Center, College of Pharmacy \& Stephenson Cancer Center, Oklahoma City, Oklahoma, USA

\section{Twitter Follow Ahmed Altyar at @aealtyar}

Preliminary findings of this study were presented as a plenary presentation at the Western States Conference for Pharmacy Residents, Fellows, Preceptors and Sponsors, 21-24 May 2012, Pacific Grove, California, USA, and as a poster at the American Society of Health-System Pharmacists ASHP Summer Meeting and Exhibition, 31 May-4 June 2014, Las Vegas, Nevada, USA.

Contributors $A A$ and $G S$ conducted the initial planning of this investigation. $A A, L K$ and GS were involved in formalising and executing the study methodology, analysis, interpretation of results, and drafting and revisions of the manuscript. GS was involved in the acquisition of data and overall study supervision.

Funding This research received no specific grant from any funding agency in the public, commercial or not-for-profit sectors.

Competing interests None declared.

Provenance and peer review Not commissioned; externally peer reviewed.

Data sharing statement No additional data are available.

Open Access This is an Open Access article distributed in accordance with the Creative Commons Attribution Non Commercial (CC BY-NC 4.0) license, which permits others to distribute, remix, adapt, build upon this work noncommercially, and license their derivative works on different terms, provided the original work is properly cited and the use is non-commercial. See: http:// creativecommons.org/licenses/by-nc/4.0/

\section{REFERENCES}

1. Governale L. Drug utilization data analysis. Joint Meeting of the Drug Safety and Risk Management Advisory Committee with the Anesthetic and Life Support Drugs Advisory Committee and the Nonprescription Drugs Advisory Committee. Briefing Information. Food and Drug Administration. 29 June 2009. http://www.fda.gov/ 
AdvisoryCommittees/CommitteesMeetingMaterials/Drugs/ DrugSafetyandRiskManagementAdvisoryCommittee/ucm171562.htm (accessed 5 May 2014).

2. Mowry JB, Spyker DA, Cantilena LR, et al. 2012 Annual report of the American Association of Poison Control Centers' National Poison Data System (NPDS): 30th annual report. Clin Toxicol 2013;51:949-1229.

3. Ostapowicz G, Fontana RJ, Schiødt FV. Results of a prospective study of acute liver failure at 17 tertiary care centers in the United States. Ann Intern Med 2002;137:947-54.

4. Larson AM, Polson J, Fontana RJ, et al. Acetaminophen-induced acute liver failure: results of a United States multicenter, prospective study. Hepatology 2005;42:1364-72.

5. Nourjah P, Ahmad SR, Karwoski C, et al. Estimates of acetaminophen (paracetomal)-associated overdoses in the United States. Pharmacoepidemiol Drug Saf 2006;15:398-405.

6. Manthripragada AD, Zhou EH, Budnitz DS, et al. Characterization of acetaminophen overdose-related emergency department visits and hospitalizations in the United States. Pharmacoepidemiol Drug Saf 2011;20:819-26.

7. Budnitz DS, Lovegrove MC, Crosby AE. Emergency department visits for overdoses of acetaminophen-containing products. $A m \mathrm{~J}$ Prev Med 2011;40:585-92.

8. $\mathrm{Li} \mathrm{C}$, Martin BC. Trends in emergency department visits attributable to acetaminophen overdoses in the United States: 1993-2007. Pharmacoepidemiol Drug Saf 2011;20:810-18.

9. U.S. Food and Drug Administration, FDA. Joint meeting of the Drug Safety and Risk Management Advisory Committee with the Anesthetic and Life Support Drugs Advisory Committee and the Nonprescription Drugs Advisory Committee: FDA briefing material. Updated 30 Jul 2013. http://www.fda.gov/AdvisoryCommittees/ Calendar/ucm 143083.htm (accessed 14 Oct 2014).

10. U.S. Food and Drug Administration, FDA. FDA Drug Safety Communication: FDA warns of rare but serious skin reactions with the pain reliever/fever reducer acetaminophen. Updated 12 Aug 2013. http://www.fda.gov/Drugs/DrugSafety/ucm363041.htm (accessed 14 Oct 2014)

11. U.S. Food and Drug Administration. FDA Drug Safety Communication: Prescription Acetaminophen Products to be Limited to $325 \mathrm{mg}$ Per Dosage Unit; Boxed Warning Will Highlight Potential for Severe Liver Failure. 2011 01/07/2014 http://www.fda.gov/drugs/ drugsafety/ucm239821.htm

12. Hornsby LB, Whitley HP, Hester EK, et al. Survey of patient knowledge related to acetaminophen recognition, dosing, and toxicity. J Am Pharm Assoc 2010;50:485-9.

13. Krenzelok EP. The FDA Acetaminophen Advisory Committee Meeting -What is the future of acetaminophen in the United States? The perspective of a committee member. Clin Toxicol 2009;47:784-9.

14. Agency for Healthcare Research and Quality, AHRQ. The Health Care Utilization Project (HCUP) Nationwide Emergency Department Sample (NEDS). http://www.hcup-us.ahrq.gov/db/nation/neds/ NEDS_Introduction_2011.jsp (accessed 27 Jun 2014).

15. Myers RP, Leung Y, Shaheen AAM, et al. Validation of ICD-9-CM/ ICD-10 coding algorithm for the identification of patients with acetaminophen overdose and hepatotoxicity using administrative data. BMC Health Serv Res 2007;7:159.

16. Prior MJ, Cooper K, Cummins P, et al. Acetaminophen availability increases in Canada with no increase in the incidence of reports of inpatient hospitalizations with acetaminophen overdose and acute liver toxicity. Am J Ther 2004;11:443-52.

17. Rangnekar AS, Ellerbe C, Durkalski V, et al. Quality of life is significantly impaired in long-term survivors of acute liver failure and particularly in acetaminophen-overdose patients. Liver Transpl 2013;19:991-1000.

18. Stravitz RT, Kramer AH, Davern T, et al. Intensive care of patients with acute liver failure: recommendations of the U.S. Acute Liver Failure Study Group. Crit Care Med 2007;35:2498-508.

19. Van Walraven C, Austin PC, Jennings A, et al. A modification of the Elixhauser comorbidity measures into a point system for hospital death using administrative data. Med Care 2009;47:626-33.

20. Skrepnek GH. Regression methods in the empirical analysis of health care data. J Manag Care Pharm 2005;11:240-51.

21. Skrepnek GH, Olvey EL, Sahai A. Econometric approaches in evaluating costs and outcomes within pharmacoeconomic analyses. Pharm Policy Law 2012;14:105-22.

22. Simes RJ. An improved Bonferroni procedure for multiple tests of significance. Biometrika 1986;73:751-4.
23. Centers for Disease Control, CDC. CDC's WISQARSTM (Web-based Injury Statistics Query and Reporting System). National Center for Injury Prevention and Control, CDC. http://www.cdc.gov/injury/ wisqars/index.html (accessed 06 May 2014).

24. Willy M, Kelly JP, Nourjah P, et al. Emergency department visits attributed to selected analgesics, United States, 2004-2005. Pharmacoepidemiol Drug Saf 2009;18:188-95.

25. McCaig LF, McCaig L, Burt CW. Poisoning-related visits to emergency departments in the United States, 1993-1996. Clin Toxicol 1999;37:817-26.

26. Chien C, Marriott JL, Ashby K, et al. Unintentional ingestion of over the counter medications in children less than 5 years old. $J$ Paediatr Child Health 2003;39:264-9.

27. Schillie SF, Shehab N, Thomas KE, et al. Medication overdoses leading to emergency department visits among children. Am J Prev Med 2009;37:181-7.

28. Vernacchio L, Kelly JP, Kaufman DW, et al. Cough and cold medication use by US children, 1999-2006: results from the Slone Survey. Pediatrics 2008;122:e323-9.

29. Centers for Disease Control, CDC. Fatal and nonfatal suicide attempts among adolescents-Oregon, 1988-1993. MMWR Morb Mortal Wkly Rep 1995;44:312-15, 321-323.

30. Kingsbury S, Hawton K, Steinhardt K, et al. Do adolescents who take overdoses have specifıc psychological characteristics? A comparative study with Psychiatric and community controls. J Am Acad Child Adolesc Psychiatry 1999;38:1125-31.

31. Hawton $\mathrm{K}$, Ware $\mathrm{C}$, Mistry $\mathrm{H}$, et al. Paracetamol self-poisoning. Characteristics, prevention and harm reduction. $\mathrm{Br} J$ Psychiatry 1996;168:43-8.

32. Centers for Disease Control, CDC. Strategies to improve external cause-of-injury coding in state-based hospital discharge and emergency department data systems: recommendations of the CDC Workgroup for Improvement of External Cause-of-Injury Coding. MMWR Recomm Rep 2008:57:1-15.

33. Centers for Disease Control, CDC. National Center for Injury Prevention and Control recommended actions to improve external-cause-of-injury coding in state-based hospital discharge and emergency department data systems. Atlanta (GA): US Department of Health and Human Services. Centers for Disease Control and Prevention, 2009.

34. Alexander GC, Mohajir N, Meltzer DO. Consumers' perceptions about risk and access to nonprescription medications. J Am Pharm Assoc 2005;45:363-70.

35. Osborne ZP, Bryant SM. Patients discharged with a prescription for acetaminophen-containing narcotic analgesics do not receive appropriate written instructions. Am J Emerg Med 2003;21:48-50.

36. National Council on Patient Information and Education, NCPIE. Attitudes and beliefs about the use of over-the-counter medicines; a dose of reality. National Survey of Consumer Health Professionals, 2002.

37. Stumpf JL, Skyles AJ, Alaniz C, et al. Knowledge of appropriate acetaminophen doses and potential toxicities in an adult clinic population. J Am Pharm Assoc 2007;47:35-41.

38. Chen L, Schneider S, Wax P. Knowledge about acetaminophen toxicity among emergency department visitors. Vet Hum Toxicol 2002;44:370-3.

39. Litovitz T. Implication of dispensing cups in dosing errors and pediatric poisonings: a report from the American Association of Poison Control Centers. Ann Pharmacother 1992;26:917-18.

40. Barrett TW, Norton VC. Parental knowledge of different acetaminophen concentrations for infants and children. Acad Emerg Med 2000;7:718-21.

41. Eiland LS, Salazar ML, English TM. Caregivers' perspectives when evaluating nonprescription medication utilization in children. Clin Pediatr 2008;47:578-87.

42. Simon HK, Weinkle DA. Over-the-counter medications. Do parents give what they intend to give? Arch Pediatr Adolesc Med 1997;151:654-6.

43. Lokker N, Sanders L, Perrin EM, et al. Parental misinterpretations of over-the-counter pediatric cough and cold medication labels. Pediatrics 2009;123:1464-71.

44. Sobhani P, Christopherson J, Ambrose PJ, et al. Accuracy of ora liquid measuring devices: comparison of dosing cup and oral dosing syringe. Ann Pharmacother 2008;42:46-52.

45. Cham E, Hall L, Ernst AA, et al. Awareness and use of over-the-counter pain medications: a survey of emergency department patients. South Med J 2002;95:529-35. 